\title{
Liquid Crystalline Benzoic Acid Ester MIDA Boronates: Synthesis and Mesomorphic Properties
}

\author{
Christopher Schilling $^{\text {a }}$ \\ Finn Schulz ${ }^{a}$ \\ Andreas Köhn' (D) \\ Sabine Laschat*a (D) \\ ${ }^{a}$ Institut für Organische Chemie, Universität Stuttgart, Pfaffenwaldring 55, 70569 \\ Stuttgart, Germany \\ ${ }^{\mathrm{b}}$ Institut für Theoretische Chemie, Universität Stuttgart, Pfaffenwaldring 55, 70569 \\ Stuttgart, Germany \\ sabine.laschat@oc.uni-stuttgart.de
}

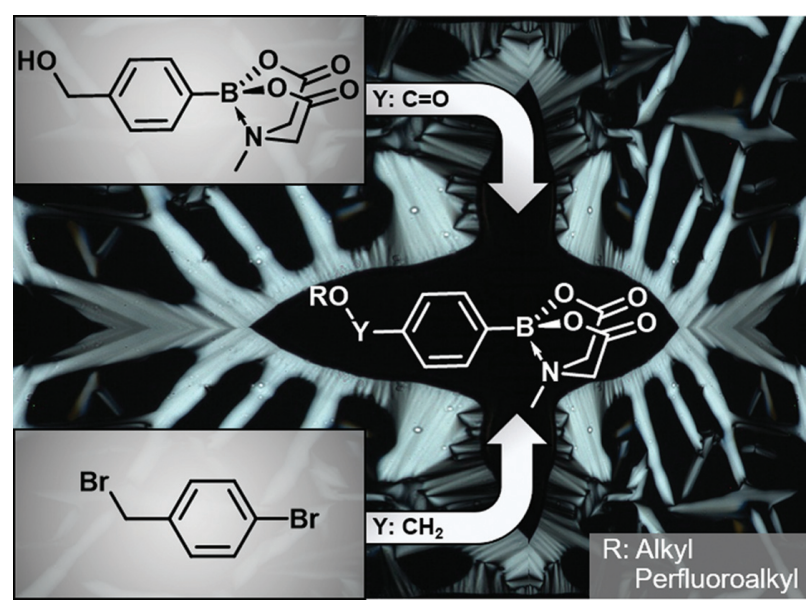

and 2 have been utilized to probe the stabilization of thermotropic mesophases by Coulomb and dipolar interactions (Scheme 1). ${ }^{23,26}$ For example, isosteric and isoelectronic replacement of the apical C-C bond in carbaborates $1 \mathbf{a}$ by N-B (1b) not only increased the longitudinal dipole moment by an order of magnitude, but also stabilized the nematic $(\mathrm{N})$ phase by $55 \mathrm{~K}^{23}$ However, reversal of the carbon position in the carbaborate cluster $\mathbf{2 a}$ increased the dipole moment but led to a very high melting point and disappearance of the smectic $A$ (SmA) phase. ${ }^{26}$

Another powerful tool in the design of liquid crystals is perfluoroalkyl chains, which show higher polarity and rigidity than alkyl chains favoring nanosegregation and formation of mesophases. ${ }^{29}$ Terminal semifluorinated chains in combination with rod-like structures such as cyanobiphenyls, ${ }^{30}$ alkoxybenzoates, ${ }^{31}$ and Schiff's base systems ${ }^{32}$ stabilize SmA and SmC phases and show high thermal

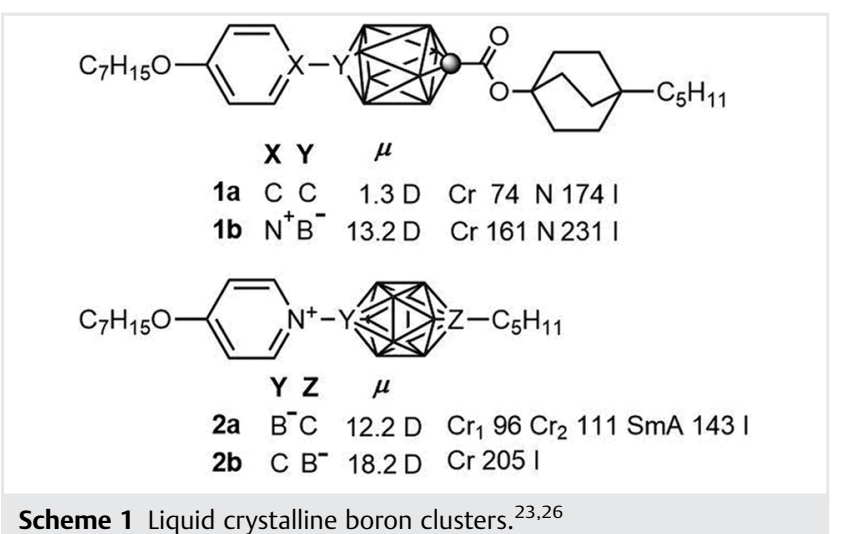




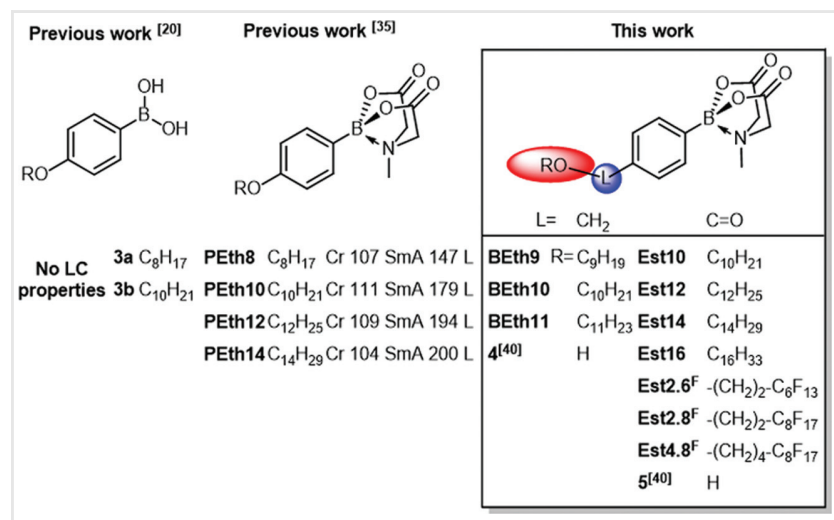

Figure 1 Boronic acid $3,{ }^{20}$ liquid crystalline MIDA boronates Peth ${ }^{35}$ and Beth; Est presented in this work.

stability. Furthermore, the successful application on bentcore structures such as naphthalene, ${ }^{33}$ viologen, and oxadiazolyl bipyridine ${ }^{34}$ was reported.

Previously, we disclosed that $p$-alkoxyphenyl boronates PEth carrying the $N$-methyliminodiacetic acid (MIDA) unit as a protecting group at boron displayed stable $\operatorname{SmA}$ mesophases in contrast to the corresponding boronic acids 3 with similar chain lengths (Figure 1). ${ }^{35}$ Quantumchemical calculations showed that the longitudinal dipole moment of the MIDA boronates PEth is three times larger than those of the boronic acids 3. Furthermore, the computational study in combination with solid-state structures yielded dipole distributions and provided a model for the liquid crystalline self-assembly of these MIDA boronates PEth. In the previous work, mesophase induction was achieved by variation of the charge distribution in the "boron head group" and the phase type was governed mostly by the number of side chains, ${ }^{35}$ i.e. exclusion of free volume. ${ }^{36}$ We surmised that attaching a nonpolar (methylene) or polar (carboxylate) linker opposite to the MIDA unit at the aryl ring should affect both mesophase stability, i.e. clearing temperature, and temperature range of the mesophase. Furthermore, by utilizing the fluorophobic effect, $^{29}$ i.e. replacing flexible alkyl side chains by more rigid and more polar partially fluorinated side chains, the mesomorphic properties should be modified as well. In the current manuscript, we describe the dipole moment variation via linkers and side chains by synthesizing MIDA boronates BEth and Est.

Although protective group chemistry, subsequent functionalization and cross-coupling of MIDA boronates have been extensively studied, ${ }^{37-39}$ and both precursors, 4-MIDA boronato benzylic alcohol $4\left(\mathrm{~L}=\mathrm{CH}_{2}\right)$ and 4-MIDA boronato benzoic acid $5(\mathrm{~L}=\mathrm{C}=\mathrm{O})$ respectively, are known compounds ${ }^{40}$; the corresponding ethers and esters are quite rare. Thus, we anticipated that the synthesis of compounds BEth and Est might not only lead to new insights from a materials perspective but also require new synthetic methods. Our results, which are reported below, show that this is indeed the case.

\section{Results and Discussion}

The synthesis of MIDA boronate benzyl ethers BEth is shown in Scheme 2. Commercially available 4-MIDA boronato benzylic alcohol 4 was treated with $\mathrm{NaH}$ and 1bromodecane in DMF at room temperature following a method by Jin et al. (route A). ${ }^{41}$

However, after $16 \mathrm{~h}$ no trace of decylether BEth10 could be detected. Thus, an alternative protocol was developed for the Williamson etherification (route $\mathrm{B}$ ). 4-Bromobenzylbromide 6 was treated with $\mathrm{NaH}$ and the respective alcohol in DMF for $16 \mathrm{~h}$ at $0{ }^{\circ} \mathrm{C}$ and warmed to room temperature and the desired ethers $\mathbf{7 a , b}$ were isolated in $73 \%$ and $69 \%$, respectively. Subsequent reaction with $n$-BuLi and triisopropylborate in THF at $-78{ }^{\circ} \mathrm{C}$, followed by addition of MIDA in DMSO at $125^{\circ} \mathrm{C}$, yielded the MIDA boronates Beth9 and BEth11 in 65\% and 63\%, respectively, without any event.

Next, the synthesis of the esters Est was examined (Scheme 3). Jones oxidation of $\mathbf{4}$ provided the known MIDA boronate benzoic acid $\mathbf{5} .^{40}$ Attempted esterification of 5 with 1-decanol under Steglich conditions with $N, N$-dicyclohexylcarbodiimide (DCC) or 1-ethyl-3-(3-dimethylaminopropyl) carbodiimide (EDCI) and $\mathrm{DMAP}^{42}$ did not meet with any success, even when different solvents were tested (for details, see Table S1, Supplementary Information). Also, the reaction of 5 with thionyl chloride followed by treatment with sodium decanolate did not give the desired product Est10. Next, Yamaguchi conditions were tested, ${ }^{43}$ but no trace of the ester Est10 could be detected. After these unsuccessful trials, we turned our attention to the Mitsunobu esterification (Scheme 3 and Table 1). Thus, acid 5 was treated with 1-decanol, triphenylphosphine, and diethyl azodicarboxylate (DEAD) in THF. Reaction monitoring by ${ }^{1} \mathrm{H}$ NMR revealed $20 \%$ conversion to the ester Est10 after $14 \mathrm{~h}$ at room temperature (entry 1). Replacement of DEAD by diisopropyl azodicarboxylate (DIAD) and an increase of the temperature to $60^{\circ} \mathrm{C}$ gave an increased yield of $40 \%$ of Est10, albeit with only $85 \%$ purity due to contamination with triphenylphosphine oxide, which could not be separated by column chromatography (entry 2 ). Despite variations of the workup procedure, ${ }^{44}$ complete removal of triphenylphosphine oxide was not possible. Next, we tested a method by Boger ${ }^{45}$ employing tri- $n$-butylphosphine, which gave 43\% yield of the product Est10 but still with low purity (80\%; entry 3 ). In a final attempt, trimethylphosphine was employed together with DIAD in THF at room temperature. Luckily, this procedure provided the desired ester Est 10 in 53\% yield in the pure form (entry 4). In order to prevent oxidation of the trimethylphosphine, special 
<smiles></smiles>

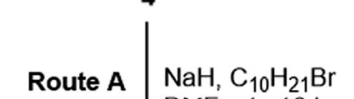
DMF, r.t., $16 \mathrm{~h}$<smiles>[R6]CO[R6]</smiles>

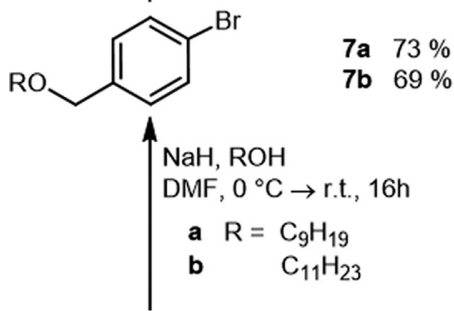<smiles>BrCc1ccc(Br)cc1</smiles><smiles>CN(CC(=O)O)CC(=O)O</smiles>

Scheme 2 Synthetic route of BEth.

precautions, e.g. a rigorous Schlenk technique, must be taken to exclude oxygen. By using this optimized protocol, the homologous ester derivatives Est12, Est14, and Est16 as well as the esters with fluorinated side chains Est2.6 ${ }^{\mathbf{F}}$, Est2.8 $\mathbf{F}$, and Est4.8 ${ }^{\mathbf{F}}$ could be obtained in 43-65\% yield (Scheme 3).

Liquid crystalline properties of compounds BEth and Est were analyzed by differential scanning calorimetry (DSC), polarizing optical microscopy (POM), and X-ray diffraction [small-angle X-ray scattering (SAXS) and wide-angle $\mathrm{X}$ ray scattering (WAXS)]. The DSC results are summarized in Table 2. Benzylic ethers BEth9 and Beth11 showed enantiotropic mesomorphism in the DSC. Upon heating of benzylic ether BEth9 with $\mathrm{C}_{9} \mathrm{H}_{19}$ chains, an endothermal melting transition at $105{ }^{\circ} \mathrm{C}$ followed by isotropization at $147{ }^{\circ} \mathrm{C}$ were observed (Table 2 ).

Upon cooling, the mesophase reappeared at $146{ }^{\circ} \mathrm{C}$ and the glass transition at $102{ }^{\circ} \mathrm{C}$ was hardly visible. The derivative BEth11 with $\mathrm{C}_{11} \mathrm{H}_{23}$ chains behaved similarly. In the series of esters Est10-Est16, the derivative Est10 with $\mathrm{C}_{10} \mathrm{H}_{21}$ chains was nonmesomorphic and showed an isotropic

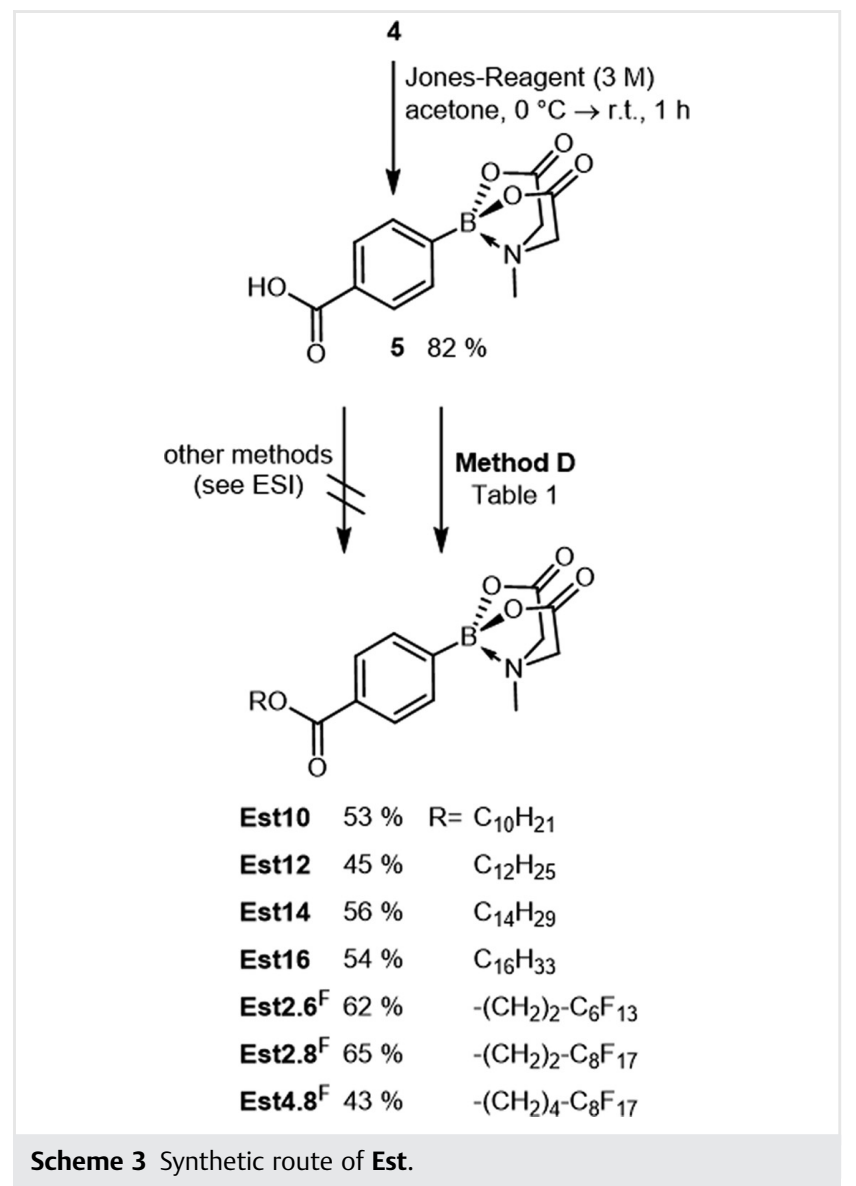

melting transition at $131{ }^{\circ} \mathrm{C}$ (Table 2). In contrast, esters Est12 and Est14 displayed enantiotropic mesophases, e.g. for homologue Est12 a crystallization at $74{ }^{\circ} \mathrm{C}$, an endothermal melting transition at $134{ }^{\circ} \mathrm{C}$, and an endothermal clearing transition at $152^{\circ} \mathrm{C}$ were detected upon heating. In the cooling cycle, only isotropic to mesophase transitions at $152^{\circ} \mathrm{C}$ and a glass transition at $62{ }^{\circ} \mathrm{C}$ were detected.

For all fluorinated derivatives Est2.6 ${ }^{\mathbf{F}}$, Est2.8 $\mathbf{F}$, and Est4.8 ${ }^{\mathbf{F}}$, decomposition was observed during the first heating cycle. Melting transitions into the liquid crystalline phase were visible at $160{ }^{\circ} \mathrm{C}$ for the shortest chain-length Est2.6 ${ }^{\mathbf{F}}$. The longer perfluoro derivative Est2.8 $\mathbf{F}$ melted at $176^{\circ} \mathrm{C}$, whereas Est4.8 $8^{\mathrm{F}}$ melted at $169{ }^{\circ} \mathrm{C}$. Upon further heating, additional endothermal decomposition peaks were observed at $240{ }^{\circ} \mathrm{C}$ for Est2.6 ${ }^{\mathbf{F}}, 287^{\circ} \mathrm{C}$ for Est2.8 ${ }^{\mathbf{F}}$, and $268^{\circ} \mathrm{C}$ for Est4.8 ${ }^{\mathbf{F}}$. During subsequent heating and cooling cycles, no transitions were observed.

During our investigation using a polarizing optical microscope of benzyl ether Beth9, we observed uncharacteristic textures (Figure 2a); however, Beth11 showed large 
Table 1 Esterification of 5 under Mitsunobu reaction conditions ${ }^{\mathrm{a}}$ to decyl ester Est10

\begin{tabular}{|c|c|c|c|c|}
\hline Entry & Reagents & Temp. & Method & Yield (purity $\left.{ }^{b}\right)$ \\
\hline 1 & $\mathrm{DEAD}, \mathrm{PPh}_{3}$ & r.t. & A & $20 \%(<85 \%)$ \\
\hline 2 & $\mathrm{DIAD}, \mathrm{PPh}_{3}$ & $60{ }^{\circ} \mathrm{C}$ & B & $40 \%(85 \%)$ \\
\hline 3 & $\mathrm{DIAD}, \mathrm{PBu}_{3}$ & r.t. & C & $43 \%(80 \%)$ \\
\hline $4^{c}$ & DIAD, $\mathrm{PMe}_{3}$ & r.t. & D & $53 \%(>99 \%)$ \\
\hline
\end{tabular}

Table 2 DSC results of different MIDA boronates: Phase transition temperatures $T$ are given in ${ }^{\circ} \mathrm{C}$ and the transition enthalpies in $\mathrm{kJ} / \mathrm{mol}^{\mathrm{a}}$

\begin{tabular}{|c|c|c|c|c|c|c|c|c|}
\hline Compound & Cycle & $\mathrm{Cr} 1$ & $\operatorname{Tm}(\Delta H)$ & $\mathrm{Cr} 2$ & $T(\Delta H)$ & SmA & $T c(\Delta H)$ & 1 \\
\hline \multirow[t]{2}{*}{ BEth9 } & 2nd heat & - & $105(14.7)$ & & & - & $147(1.3)$ & - \\
\hline & 2nd cool & G & $102(-)$ & & & • & $146(-1.7)$ & • \\
\hline \multirow[t]{2}{*}{ BEth11 } & 2nd heat & G & $110(-)$ & & & • & $161(1.4)$ & - \\
\hline & 2nd cool & G & $108(-)$ & & & - & $158(-1.7)$ & - \\
\hline Est10 & 1st heat & • & $131(-)$ & & & & & • \\
\hline \multirow[t]{2}{*}{ Est12 } & 2nd heat & G & $74(-32.2)$ & • & $134(46.8)$ & • & $152(3.7)$ & • \\
\hline & 2nd cool & G & $62(-)$ & & & - & $152(-3.1)$ & - \\
\hline \multirow[t]{2}{*}{ Est14 } & 2nd heat & • & $71(6.3)$ & • & $145(12.4)$ & • & $176(1.0)$ & - \\
\hline & 2nd cool & • & $63(-5.1)$ & • & $77(-4.1)$ & • & $176(-1.0)$ & - \\
\hline \multirow[t]{2}{*}{ Est16 } & 2nd heat & • & 74 (12.4) & • & $140(11.6)$ & • & $183(0.9)$ & - \\
\hline & 2nd cool & - & $64(-14.5)$ & & & - & $182(-1.2)$ & • \\
\hline Est2. $6^{\mathrm{F}}$ & 1st heat & - & $160(24.9)$ & & & - & $240(6.7)$ & $\bullet$ \\
\hline Est2.8 & 1st heat & - & $176(27.1)$ & & & - & $287(7.2)$ & b \\
\hline Est4. $8^{\mathrm{F}}$ & 1st heat & - & $169(82.8)$ & & & - & $268(5.2)$ & , \\
\hline
\end{tabular}

a Heating/cooling rate $10 \mathrm{~K} / \mathrm{min}$. Phase transitions were determined during $1 \mathrm{st}$ heating cycle for Est10, Est2. $6^{\mathrm{F}}$, Est2.8 $\mathrm{F}^{\mathrm{F}}$, and Est4.8 ${ }^{\mathrm{F}}$, and during 2nd heating/ cooling for BEth9, BEth11, Est12, Est14, and Est16.

becomposition during 1st heating cycle.

areas of homeotropic alignment with small maltese crossdefects (Figure S6), despite the use of silylated slides. Furthermore, we observed a similar behaviour for MIDA boronates Est12-16, Est2.6 ${ }^{\mathrm{F}}$, Est2.8 ${ }^{\mathrm{F}}$, and Est4.8 ${ }^{\mathrm{F}}$. While compounds Est12 (Figure 2b) and perfluoro esters Est2.6 $\mathbf{F}$, Est2.8 $\mathbf{F}$, and Est4.8 ${ }^{\mathbf{F}}$ (Figure 2e, f) showed uncharacteristic textures, compounds Est14 and Est16 showed large areas of homeotropic alignment with small defects (Figure 2c).

A phenomenon we observed for all samples was the formation of filament-like textures after shearing of the cover glasses, indicating an SmA phase (Figure 2d). These observations are similar to the behavior of the previously published MIDA boronates. ${ }^{35}$ With the observations under the polarizing microscope and the structural resemblance to our previously published boronates, we surmised a smectic mesophase. The findings of DSC experiments for perfluorinated derivatives Est2.6 ${ }^{\mathbf{F}}$, Est2.8 ${ }^{\mathbf{F}}$, and Est4.8 ${ }^{\mathbf{F}}$ are in accordance with observations under the polarizing micro- scope. We observed uncharacteristic textures for the perfluorinated derivatives Est2.6 $F$, Est2.8 ${ }^{F}$, and Est4.8 ${ }^{F}$ upon heating and slow fading at higher temperatures. No textures were observed during later heating and cooling cycles. This was another indication for decomposition of the samples at high temperatures.

To obtain a deeper insight into the mesophase geometries, for one member of each series, SAXS and WAXS measurements were conducted (Table 3 ). The diffractogram of BEth9 is shown in Figure 3a. In the small-angle area, the (001) reflection is displayed. Moreover, in the wide-angle area, a broad halo was visible. To clarify the phase geometries, temperature-dependent SAXS measurements were conducted. From the (001) X-ray diffractions for derivatives BEth9 and Est16, the layer spacing $d$ was calculated. The layer spacings with the corresponding temperatures are shown in Figure 3b.

During cooling, a gradual increase in the layer spacing was observed. This is a typical phenomenon observed for SmA phases, presumably due to decreasing interdigitation of side chains. During DSC measurements for perfluoro derivatives, we observed a decomposition of the compounds. Therefore, we were not able to gather sufficient data for evaluation from the SAXS measurement of Est2.6 $\mathbf{F}$. Fortunately, it was possible to conduct temperaturedependent WAXS experiments before decomposition started. Similar to the above-discussed experiments, an increase of the layer spacing $d$ during cooling was observed.

To compare the layer spacings among each series, we calculated the reduced layer spacing $d_{\text {red }}$ from the layer spacing trend lines at the reduced clearing temperature $\left(0.95 \times T_{\mathrm{c}}\right)$. For comparison, the molecular lengths in the alltrans-configuration were estimated using the Avogadro program $^{46}$ (molecular mechanics, force field: MMFF94s). The molecular length of nonyl ether BEth9 was determined between the outer most atoms to be $20.8 \AA$ and the reduced layer spacing to be $d_{\text {red }}=29.6 \AA$. $d_{\text {red }}$ is larger than the molecular length $(L)$ but shorter than the twofold molecular length $(2 L)$, indicating an interdigitation of the side chains. However, the calculated layer spacing for full interdigitation is in good agreement with $d_{\text {red }}\left(d_{\text {cal }}=31.5 \AA\right)$. For the alkoxy ester Est 16, the reduced layer spacing $d_{\text {red }}$ is $39.3 \AA$, which is in good agreement with the calculated value for fully interdigitated side chains $\left(d_{\text {cal }}=38.1 \AA\right.$ ). Furthermore, the molecular length of perfluoro ester Est2.6 ${ }^{\mathbf{F}}$ was determined to be 21.1 $\AA$ and the reduced layer spacing $d_{\text {red }}$ to be $36.9 \AA$.

To rationalize the large volume $d_{\text {red }}$, we propose that the fluorophobic effect as well as the steric demand of the fluorinated tails leads to nanosegregation and an unfavorable interdigitation of the chain as observed for derivatives with alkyl ethers (BEth9) and alkoxy esters (Est16), respectively (Figure $4 \mathrm{a}$ ). Instead the core fragments are stacked as shown in Figure $4 \mathrm{~b}$. 


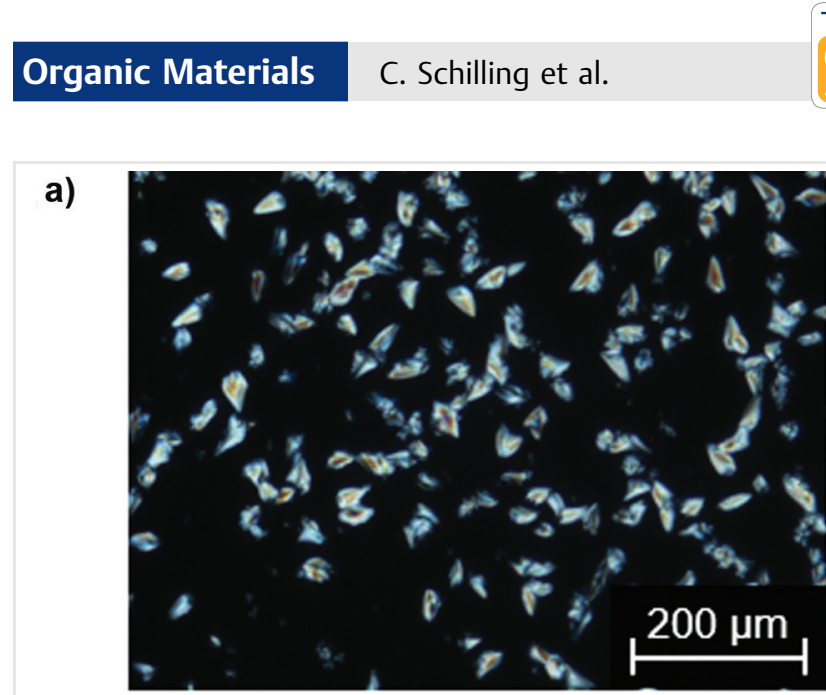

c)

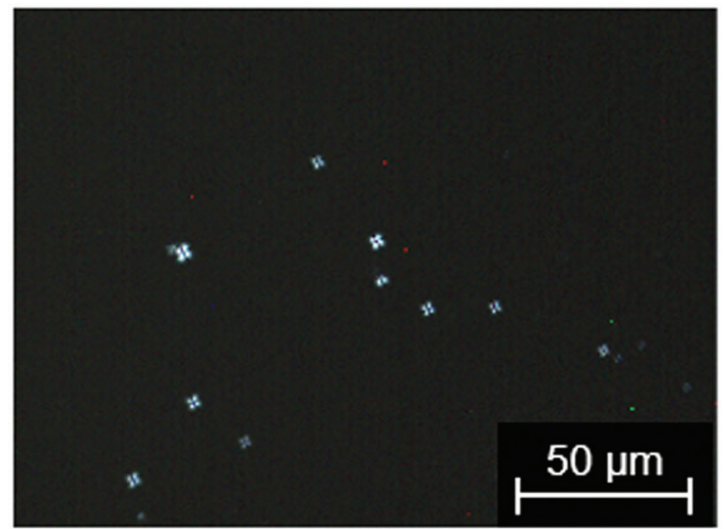

e)

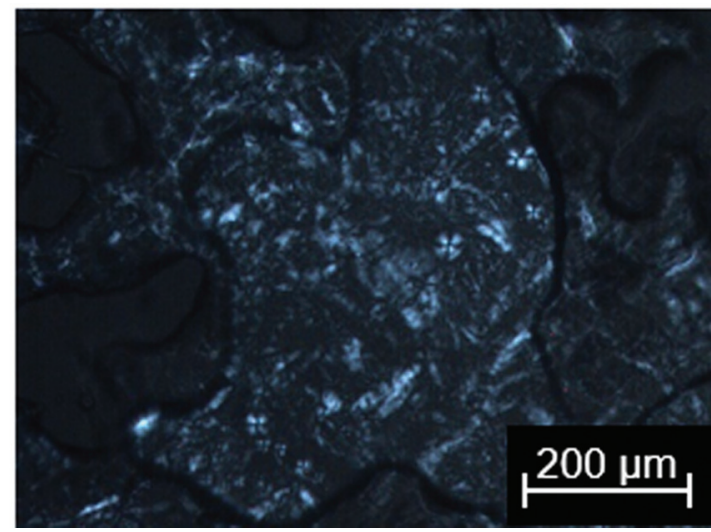

b)

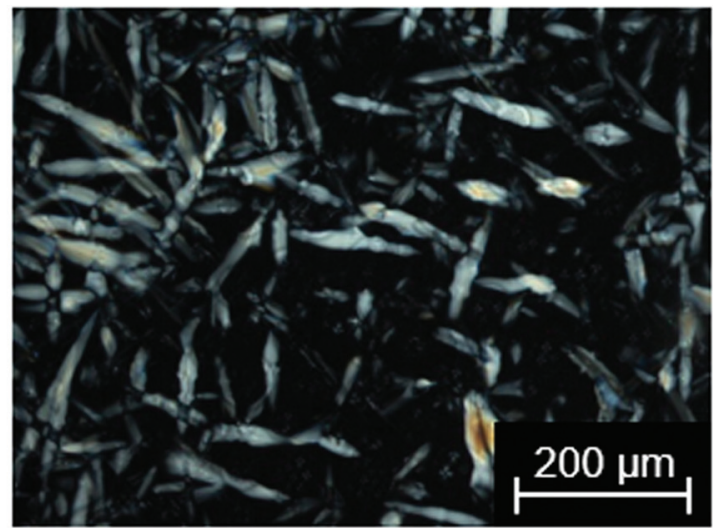

d)

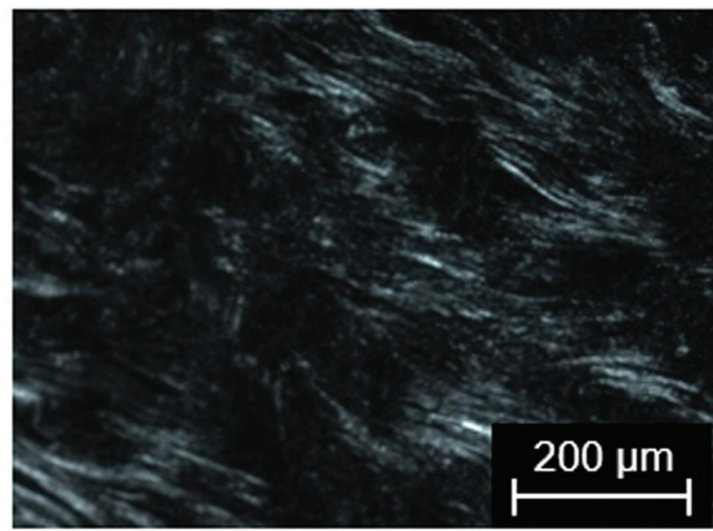

f)

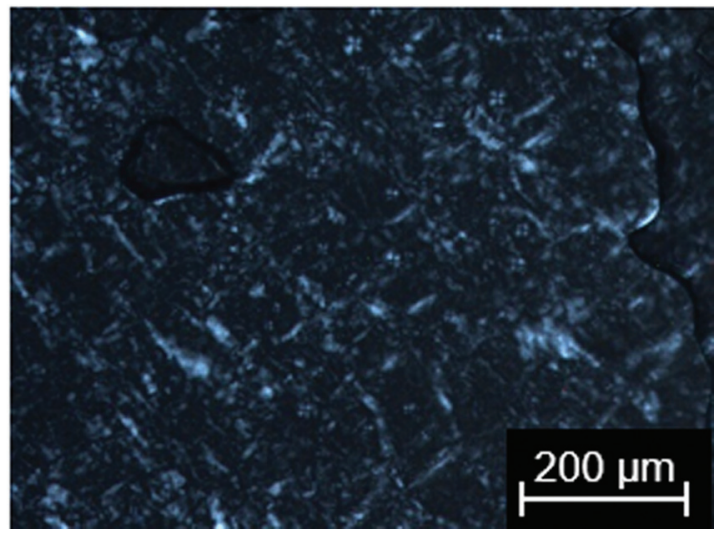

Figure 2 Observed POM textures of nonyl ether BEth9 at $152{ }^{\circ} \mathrm{C}$ (a); dodecyl ester Est12 at $150{ }^{\circ} \mathrm{C}(\mathbf{b})$; hexadecyl ester Est16 at $165{ }^{\circ} \mathrm{C}(\mathbf{c})$; and after shearing (d); perfluorodecyl ester Est2.8 ${ }^{\mathbf{F}}$ at $230^{\circ} \mathrm{C}(\mathbf{e}, \mathbf{f})(200 \times$ magnification).

Upon comparison of MIDA boronate benzyl ethers BEth9 and BEth11 with the corresponding MIDA boronate aryl ethers Peth, ${ }^{35}$ the additional methylene group did not affect the melting transition but decreased the clearing point considerably (compare, e.g., PEth10 vs. BEth9 and PEth12 vs. BEth11) by $30 \mathrm{~K}$.
In contrast, the additional "anti-periplanar" dipole introduced by the carboxylate moiety resulted in a slightly reduced longitudinal dipole moment. However, the slightly bent ester led to the appearance of a second crystalline phase (temperature range: $60-70 \mathrm{~K}$ ) and an SmA phase (phase widths: 18-43 K) for Est12-Est16. However, the known tendency of 


\begin{tabular}{llll}
\hline \multicolumn{2}{l}{ Table 3 XRD data of derivatives BEth9, Est16, and Est2.6 } & \\
\hline Compd. & Mesophase & $\begin{array}{l}d \text { Values (Å), } \\
\text { expt. (calcd.) }\end{array}$ & $\begin{array}{l}\text { Miller } \\
\text { indices }\end{array}$ \\
\hline BEth9 & SmA at $140{ }^{\circ} \mathrm{C}$ & $30.2(-)$ & $(001)$ \\
& & 4.9 & Halo \\
Est16 & SmA at $150{ }^{\circ} \mathrm{C}$ & $39.0(-)$ & $(001)$ \\
& & 4.40 & Halo \\
Est2.6 $\mathbf{F}^{\mathbf{F}}$ & $\mathrm{SmA}$ at $225^{\circ} \mathrm{C}$ & $38.6(-)$ & $(001)$ \\
& & $19.2(19.3)$ & $(002)$ \\
& & $12.8(12.9)$ & $(003)$ \\
& & 5.7 & Halo \\
\hline
\end{tabular}
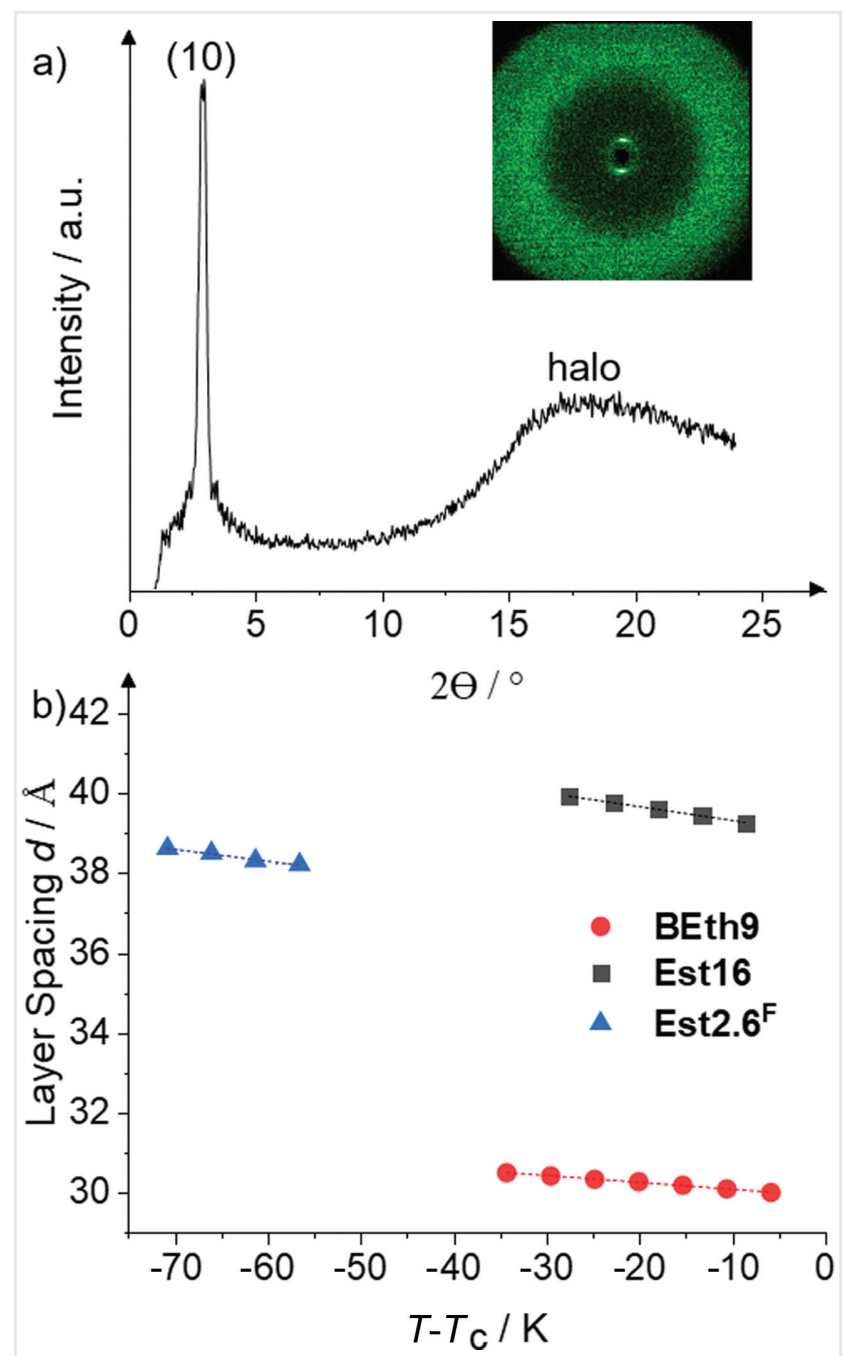

Figure 3 (a) WAXS diffractogram of Beth9 at $140{ }^{\circ} \mathrm{C}$ and 2D X-ray pattern (inset). (b) Temperature-dependent layer spacing $d$ of Beth9, Est16, and Est2.6.

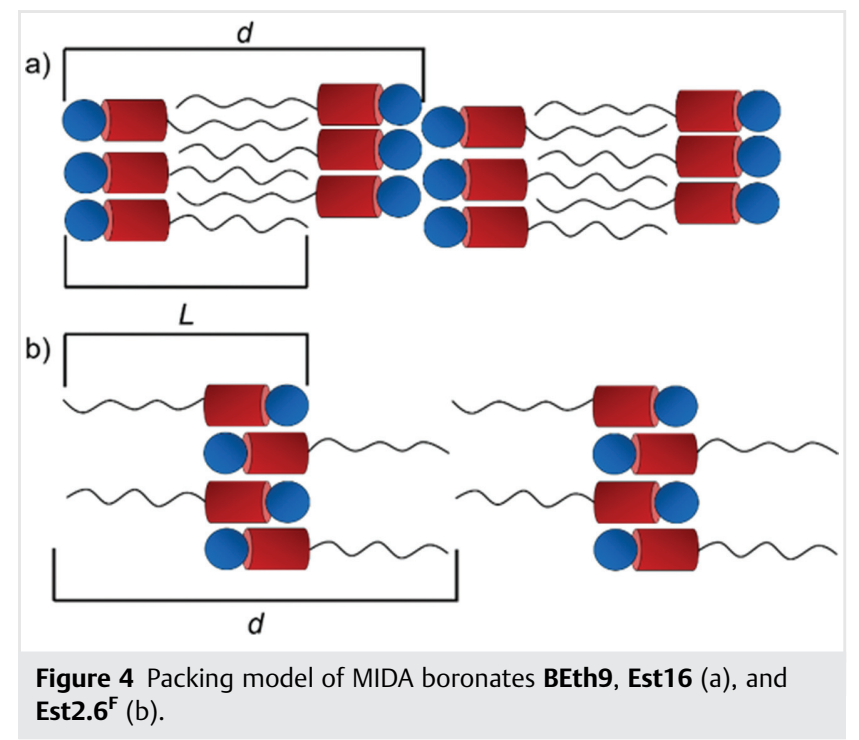

fluorinated or partially fluorinated side chains to reduce the conformational mobility ${ }^{29,47}$ significantly stabilized the SmA phase up to the thermal decomposition at $240-287^{\circ} \mathrm{C}$.

In addition, melting points also increased by $80-100 \mathrm{~K}$ and thus the overall mesophase widths increased up to $37 \mathrm{~K}$ as compared to the nonfluorinated analogues.

To obtain further insight into the packing model, we performed quantum-chemical calculations (for details, see the Experimental Section, quantum chemical calculations). In our previous studies, a negligible impact of chain length on the electronic core structure of MIDA boronates PEth8-PEth14 was observed. This prompted us to use MIDA boronates with ethoxy side chains as model systems in the calculations. Here, we use the compound BEth2 as a model for all compounds with a methylene linker and Est2 as a model for all compounds with a carboxylate linker. One of the first findings of our computations was that the overall dipole moment of the two compounds was not strongly affected by the linker group. We calculated a value of 7.1 D for both BEth2 and Est2, which is only slightly smaller than the dipole moment of alkoxy ether PEth2 (7.6 D; Figure 5). More insight was provided by plotting the electrostatic potential of BEth2, Est2, and PEth2 (Figure 6). The plot of PEth2 (Figure 6c) indicates that there is no strong variation of the electrostatic potential in the vicinity of the phenyl oxygen, whereas BEth2 and Est2 (Figure 6a, b) show a strong contribution of the negatively charged oxygen atoms to the electrostatic potential. This will likely induce repulsive interactions between neighboring side chains and lead to decreased interdigitation of these.

Furthermore, ester Est2 and ether BEth2 exhibit a slightly bent structure of the side chain in comparison to nearly linear compound PEth2. This bending of BEth2 and Est2 leads to a larger occupied volume fraction and an unfavorable space filling in the liquid-crystalline phase, resulting in decreased clearing temperatures for benzyl 


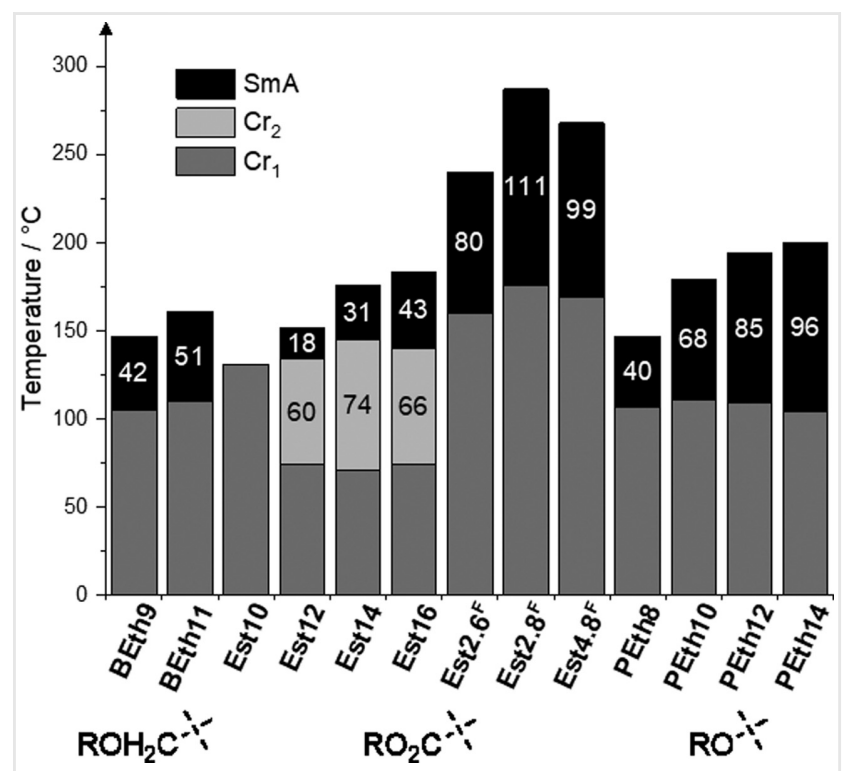

Figure 5 Phase transition diagram of MIDA boronates Est10-Est16, Est2.6 ${ }^{\mathrm{F}}$, Est2.8 ${ }^{\mathrm{F}}$, Est4.8 ${ }^{\mathrm{F}}$, BEth9, BEth11, and PEth8-PEth14. Values for PEth8-PEth14 were taken from Wöhrle et al. ${ }^{35}$ for comparison.

ethers BEth9 and BEth11 and a second crystalline phase for alkyl esters Est12-Est16. The bending of MIDA boronate ester Est2 formed in the calculations also explains why compounds Est12-Est16 with alkyl side chains have lower melting and clearing points together with smaller phase widths as compared with the derivatives Est2.6 ${ }^{\mathbf{F}}$, Est2.8 $\mathbf{F}$, and Est4.8 $\mathbf{F}^{\mathbf{F}}$ with partially fluorinated side chains. The fluorinated tails of Est2.6 ${ }^{\mathbf{F}}$, Est2.8 $\mathbf{F}$, and Est4.8 ${ }^{\mathbf{F}}$ are stiffer and more rigid than the alkyl chains of Est2.6 ${ }^{\mathbf{F}}$, Est2.8 ${ }^{\mathbf{F}}$, and Est4.8 $\mathbf{F}$, and they tend to pack more tightly due to fluorinefluorine interactions. Thus, even a short fluorinated tail and an overall shorter total chain length can outperform a much longer alkyl chain; see for example Est16 vs. Est2.6F ${ }^{\mathbf{F}}$.

\section{Conclusions}

In conclusion, a convenient synthetic access to both MIDAboronate benzyl ethers BEth9 and BEth11 and MIDA boronate esters Est10-Est16, Est2.6 ${ }^{\mathbf{F}}$, Est2.8 ${ }^{\mathrm{F}}$, and Est4.8 ${ }^{\mathrm{F}}$, respectively, has been developed. Key steps were Williamson etherification of 4-bromobenzyl bromide and late-stage borylation in the case of BEth9 and BEth11, while MIDA boronate carboxylic acid 5 could be successfully esterified under Mitsunobu conditions to Est10-Est16, Est2.6 ${ }^{\mathrm{F}}$, Est2.8 ${ }^{\mathrm{F}}$, and Est4.8 ${ }^{\mathrm{F}}$.

Except for compound Est10, all other MIDA boronates showed SmA phases, with particularly broad phases for MIDA boronate esters Est2.6 ${ }^{\mathbf{F}}$, Est2.8 $\mathbf{F}$, and Est4.8 ${ }^{\mathbf{F}}$ with partially fluorinated tails. Their packing mechanisms and different mesomorphic properties were compared with those of the known MIDA boronate alkoxy ethers PEth8-PEth14 and rationalized by quantum-chemical calculations. Our results show that even unfavorable dipolar and electrostatic interactions as well as bending of a calamitic core can be overruled by attachment of fluorine tails resulting in the formation of broad mesophases. Thus the current work broadens the scope of MIDA boronates with respect to organic materials.

\section{Experimental Section}

NMR spectra were recorded on Bruker Avance $500\left({ }^{1} \mathrm{H}\right.$, $\left.500 \mathrm{MHz} ;{ }^{13} \mathrm{C}, 126 \mathrm{MHz}\right)$, Bruker Avance $400\left({ }^{1} \mathrm{H}, 400 \mathrm{MHz}\right.$; $\left.{ }^{13} \mathrm{C}, 100 \mathrm{MHz}\right)$, and Bruker Avance $300\left({ }^{1} \mathrm{H}, 300 \mathrm{MHz} ;{ }^{13} \mathrm{C}\right.$, $75 \mathrm{MHz}$ ). All NMR spectra were recorded at room temperature and the calibration was done on the residual solvent peaks. For calibration of NMR spectra, the residual solvent peaks were used. FT-IR spectra were recorded on a Bruker Vector 22 FT-IR spectrometer with a MKII golden gate single reflection Diamond ATR system, at room temperature. POM was performed using an Olympus BX50 polarizing microscope with a Linkam TP93 central controller. DSC measurements were performed on a Mettler Toledo DSC 822e device in aluminum pans $(40 \mu \mathrm{L})$ from Mettler Toledo. X-ray diffraction measurements (SAXS and WAXS) were conducted on a Bruker Nanostar $C$ device with a HI-STAR detector using $\mathrm{Cu}_{\mathrm{K \alpha}}$ radiation ( $\alpha=1.5418 \AA$ ) calibrated to silver behenate. TLC was done on aluminum plates precoated with silica gel $60 \mathrm{~F}_{254}$ from Merck. Flash chromatography was conducted with silica gel from Fluka (grain size: 40-63 $\mu \mathrm{m}$ ).

\section{Materials}

All commercial chemicals were used as received. Dry solvents were distilled under a nitrogen atmosphere using common drying agents prior to use. Moisture- and/or oxygen-sensitive reactions were conducted using common Schlenk techniques. The synthesis of MIDA, ${ }^{48}$ 4-(6-methyl4,8-dioxo-1,3,6,2-dioxazaborocan-2-yl) benzoic acid, ${ }^{40}$ trimethylphosphine, ${ }^{49,50}$ and ethyl 3-butenoate ${ }^{51}$ were performed according to literature procedures.

\section{Esterification: General Procedure}

MIDA acid 5 (0.10 g, $0.36 \mathrm{mmol})$, DIAD (0.09 mL, $0.47 \mathrm{mmol})$, and the respective alcohol $(0.47 \mathrm{mmol})$ were dissolved in dry THF $(10 \mathrm{~mL})$. Trimethylphosphine $(0.05 \mathrm{~mL}$, $0.47 \mathrm{mmol}$ ) was added and the reaction mixture was stirred overnight at room temperature. The solvent was removed under removed pressure. The crude product was purified by column chromatography (hexanes/ethyl acetate $1: 3 ; R_{\mathrm{f}}: 0.2$ ) and Soxhlet extraction (hexane). 
<smiles>CCOCc1ccc([B-]23OC(=O)CN(C)C(O2)C(=O)O3)cc1</smiles>

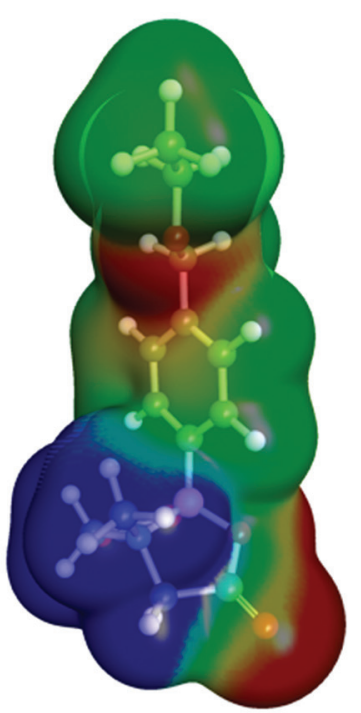

a) $7.1 \mathrm{D}$<smiles>CCOC(=O)c1ccc(B2OC(=O)CN(C)[B-]23OC(=O)CC3(C)S)cc1</smiles>

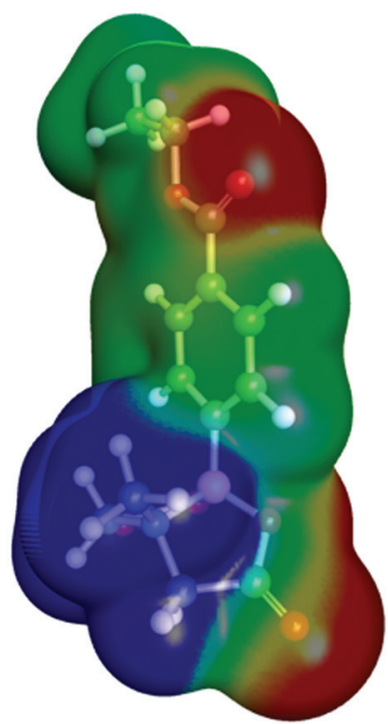

b) $7.1 \mathrm{D}$<smiles></smiles>

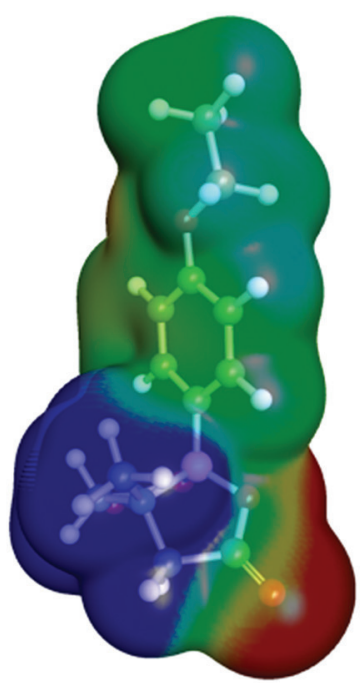

c) $7.6 \mathrm{D}$

Figure 6 Visualization of the electrostatic potential of MIDA boronates BEth2, Est2, and PEth2. The electrostatic potential is color-coded (red $=-1.9 \mathrm{eV}$ to blue $1.9 \mathrm{eV}$ ) on an isosurface of the electron density $\left(0.0067 \AA^{-3}\right)$.

\section{Decyl-4-(6-methyl-4,8-dioxo-1,3,6,2- dioxazaborocan-2-yl)benzoate (Est10)}

The general esterification procedure was followed with 5 and 1-decanol to give Est10 as a white solid (80 mg, 53\%).

${ }^{1} \mathrm{H}$ NMR (400 MHz, $\left.\mathrm{CDCl}_{3}\right): \delta=8.05(\mathrm{~d}, J=8.2 \mathrm{~Hz}, 2 \mathrm{H}$, 3-H), 7.61 (d, $J=8.2 \mathrm{~Hz}, 2 \mathrm{H}, 2-\mathrm{H}), 4.32(\mathrm{t}, J=6.7 \mathrm{~Hz}, 2 \mathrm{H}$, $\left.\mathrm{OCH}_{2}\right), 3.95\left(\mathrm{~d}, J=16.4 \mathrm{~Hz}, 2 \mathrm{H}, 1^{\prime}-\mathrm{H}\right), 3.78(\mathrm{~d}, J=16.4 \mathrm{~Hz}, 2 \mathrm{H}$, 1'-H), 2.55 (s, 3H, $\left.\mathrm{NCH}_{3}\right), 1.71-1.82(\mathrm{~m}, 2 \mathrm{H}), 1.20-1.49(\mathrm{~m}$, $\left.14 \mathrm{H}, \mathrm{CH}_{2}\right), 0.84-0.93\left(\mathrm{~m}, 3 \mathrm{H}, \mathrm{CH}_{3}\right), \mathrm{ppm} .{ }^{13} \mathrm{C} \mathrm{NMR}(101 \mathrm{MHz}$, $\left.\mathrm{CDCl}_{3}\right): \delta=166.7(\mathrm{C}=0), 166.52(\mathrm{C}-5), 132.25(\mathrm{C}-2), 132.04$ (C-4), 129.29 (C-3), $65.32\left(\mathrm{OCH}_{2}\right), 61.90\left(\mathrm{C}-1^{\prime}\right), 47.45\left(\mathrm{NCH}_{3}\right)$, 31.89, 29.53, 29.30, 28.72, 26.03, $22.67\left(\mathrm{CH}_{2}\right), 14.10\left(\mathrm{CH}_{3}\right)$ ppm.FT-IR(ATR): 2956(w), 2924(s), 2854(w), 2178(w), 2039 (w), $1761(\mathrm{~s}), 1718(\mathrm{~s}), 1562(\mathrm{w}), 1507(\mathrm{w}), 1458(\mathrm{w}), 1430(\mathrm{w})$, 1396 (w), 1337 (w), 1272 (vs), 1221 (s), 1186 (w), 1112 (s), 1039 (vs), 997 (s), 890 (w), 843 (s), 803 (w), 767 (s), $711(\mathrm{w})$, $648(w), 594(w), 547(w), 513(w), 482(w) \mathrm{cm}^{-1}$. MS (ESI): $m / z=440[\mathrm{M}+\mathrm{Na}]^{+}$. HRMS $(\mathrm{ESI})(m / z):[\mathrm{M}+\mathrm{Na}]^{+}$calcd. for $\mathrm{C}_{22} \mathrm{H}_{32} \mathrm{BNO}_{6} \mathrm{Na}$ : 440.2219, found: 440.2210. CHN analysis calcd. (\%) for $\mathrm{C}_{22} \mathrm{H}_{32} \mathrm{BNO}_{6}$ (417.31): C $63.32 \mathrm{H} \mathrm{7.73,} \mathrm{N} \mathrm{3.36;}$ found: C 62.34, H 7.47 N 2.83 .

\section{Dodecyl-4-(6-methyl-4,8-dioxo-1,3,6,2- dioxazaborocan-2-yl) benzoate (Est12)}

The general esterification procedure was followed with $\mathbf{5}$ and 1-dodecanol to give Est12 as a white solid (73 mg, 45\%).

${ }^{1} \mathrm{H}$ NMR $\left(500 \mathrm{MHz}, \mathrm{CDCl}_{3}\right): \delta=8.05(\mathrm{~d}, J=8.2 \mathrm{~Hz}, 2 \mathrm{H}$, 3-H), 7.61 (d, $J=8.2 \mathrm{~Hz}, 2 \mathrm{H}, 2-\mathrm{H}), 4.31(\mathrm{t}, J=6.7 \mathrm{~Hz}, 2 \mathrm{H}$, $\left.-\mathrm{OCH}_{2}\right), 4.02\left(\mathrm{~d}, J=16.4 \mathrm{~Hz}, 2 \mathrm{H}, 1^{\prime}-\mathrm{H}\right), 3.80(\mathrm{~d}, J=16.4 \mathrm{~Hz}$, $\left.2 \mathrm{H}, 1^{\prime}-\mathrm{H}\right), 2.55\left(\mathrm{~s}, 3 \mathrm{H}, \mathrm{NCH}_{3}\right), 1.72-1.80\left(\mathrm{~m}, 2 \mathrm{H}, \mathrm{OCH}_{2}\right), 1.20$ $1.38\left(\mathrm{~m}, 16 \mathrm{H}, \mathrm{CH}_{2}\right), 1.39-1.47\left(\mathrm{~m}, 2 \mathrm{H}, \mathrm{OCH}_{2} \mathrm{CH}_{2}\right), 0.87(\mathrm{t}$, $\left.J=6.9 \mathrm{~Hz}, 3 \mathrm{H}, \mathrm{CH}_{3}\right)$ ppm. ${ }^{13} \mathrm{C} \mathrm{NMR}\left(126 \mathrm{MHz}, \mathrm{CDCl}_{3}\right)$ : $\delta=167.4(\mathrm{C}=0), 166.8$ (C-5), 132.5 (C-2), 132.2 (C-4), 129.5 (C-3), $65.6\left(\mathrm{OCH}_{2}\right), 62.1\left(\mathrm{C}-1^{\prime}\right), 47.8\left(\mathrm{NCH}_{3}\right), 32.1,29.89,29.87$, 29.83, 29.79, 29.59, 29.54, 28.94, 26.2, $22.8\left(\mathrm{CH}_{2}\right), 14.38\left(\mathrm{CH}_{3}\right)$ ppm. FT-IR (ATR): 2955 (w), 2923 (s), 2854 (s), 1763 (s), 1719 (vs), $1562(\mathrm{~s}), 1508(w), 1459(w), 1396(w), 1396(w), 1337(w)$, 
1274 (vs), 1222 (s), 1186 (w), 1113 (w), 1041 (s), 996 (s), 890 $(\mathrm{w}), 843(\mathrm{w}), 767(\mathrm{w}), 711(\mathrm{w}), 650(\mathrm{w}), 594(\mathrm{w}) \mathrm{cm}^{-1}$.MS(ESI): $m / z=468[\mathrm{M}+\mathrm{Na}]^{+}$. HRMS (ESI) $(m / z):[\mathrm{M}+\mathrm{Na}]^{+}$calcd. for $\mathrm{C}_{24} \mathrm{H}_{36} \mathrm{BNO}_{6} \mathrm{Na}: 468.2532$, found: 468.2530. CHN analysis calcd. (\%) for $\mathrm{C}_{24} \mathrm{H}_{326} \mathrm{BNO}_{6}$ (445.36): C $64.73 \mathrm{H} \mathrm{8.15}$, N 3.15; found: C 64.73, H 8.22 N 3.23 .

\section{Tetradecyl-4-(6-methyl-4,8-dioxo-1,3,6,2- dioxazaborocan-2-yl) benzoate (Est14)}

The general esterification procedure was followed with $\mathbf{5}$ and 1-tetradecanol to give Est14 as a white solid (96 mg, 56\%).

${ }^{1} \mathrm{H}$ NMR $\left(700 \mathrm{MHz}, \mathrm{CDCl}_{3}\right): \delta=8.06(\mathrm{~d}, J=7.7 \mathrm{~Hz}, 2 \mathrm{H}$, 3-H), 7.61 (d, $J=7.7 \mathrm{~Hz}, 2 \mathrm{H}, 2-\mathrm{H}), 4.32(\mathrm{t}, J=6.7 \mathrm{~Hz}, 2 \mathrm{H}$, $\left.-\mathrm{OCH}_{2}\right), 3.95\left(\mathrm{~d}, J=16.3 \mathrm{~Hz}, 2 \mathrm{H}, 1^{\prime}-\mathrm{H}\right), 3.79(\mathrm{~d}, J=16.3 \mathrm{~Hz}$, $\left.2 \mathrm{H}, 1^{\prime}-\mathrm{H}\right), 2.56\left(\mathrm{~s}, 3 \mathrm{H},-\mathrm{NCH}_{3}\right), 1.74-1.80\left(\mathrm{~m}, 2 \mathrm{H},-\mathrm{OCH}_{2} \mathrm{CH}_{2}\right)$, 1.40-1.46 (m, 2H, $\left.-\mathrm{OCH}_{2} \mathrm{CH}_{2} \mathrm{CH}_{2}\right), 1.21-1.38\left(\mathrm{~m}, 20 \mathrm{H}, \mathrm{CH}_{2}\right)$, $0.88\left(\mathrm{t}, J=7.1 \mathrm{~Hz}, 3 \mathrm{H}, \mathrm{CH}_{3}\right) \mathrm{ppm} .{ }^{13} \mathrm{C} \mathrm{NMR}(176 \mathrm{MHz}$, $\left.\mathrm{CDCl}_{3}\right) \delta=166.8(\mathrm{C}=0) 166.5(\mathrm{C}-5), 132.3(\mathrm{C}-2), 132.0(\mathrm{C}-4)$, $129.3(\mathrm{C}-3), 65.3\left(\mathrm{OCH}_{2}\right), 61.9\left(\mathrm{C}-1^{\prime}\right), 47.5\left(\mathrm{NCH}_{3}\right), 31.92$, 29.70, 29.68, 29.66, 29.60, 29.55, 29.36, 29.30, 28.72, 26.04, $22.70\left(\mathrm{CH}_{2}\right), 14.13\left(\mathrm{CH}_{3}\right)$ ppm. FT-IR (ATR): 2922 (vs), 2853 (w), 1762 (s), 1719 (s), 1562 (w), 1459 (w), 1396 (w), 1337 (w), 1275 (s), $1221(\mathrm{w}), 1186(\mathrm{w}), 1114(\mathrm{w}), 1040(\mathrm{~s}), 996$ (w), $890(\mathrm{w}), 843(\mathrm{w}), 767(\mathrm{w}), 711(\mathrm{w}), 595(\mathrm{w}) \mathrm{cm}^{-1}$. MS (ESI): $m / z=496[\mathrm{M}+\mathrm{Na}]^{+}$. HRMS (ESI) $(m / z):[\mathrm{M}+\mathrm{Na}]^{+}$ calcd. for $\mathrm{C}_{26} \mathrm{H}_{40} \mathrm{BNO}_{6} \mathrm{Na}$ 496.2846, found: 497.2877. $\mathrm{CHN}$ analysis calcd. (\%) for $\mathrm{C}_{26} \mathrm{H}_{40} \mathrm{BNO}_{6}(473,42)$ : C 65.96, $\mathrm{H} 8.52$, N 2.96; found: C 65.88, H 8.68 N 2.99.

\section{Hexadecyl 4-(6-methyl-4,8-dioxo-1,3,6,2- dioxazaborocan-2-yl) benzoate (Est16)}

The general esterification procedure was followed with 5 and 1-hexadecanol to give Est16 as a white solid (98 mg, 54\%).

${ }^{1} \mathrm{H}$ NMR $\left(700 \mathrm{MHz}, \mathrm{CDCl}_{3}\right): \delta=8.05(\mathrm{~d}, J=8.0 \mathrm{~Hz}, 2 \mathrm{H}$, 3-H), 7.61 (d, $J=8.0 \mathrm{~Hz}, 2 \mathrm{H}, 2-\mathrm{H}), 4.32(\mathrm{t}, J=6.7 \mathrm{~Hz}, 2 \mathrm{H}$, $\left.-\mathrm{OCH}_{2}\right), 4.01\left(\mathrm{~d}, J=16.3 \mathrm{~Hz}, 2 \mathrm{H}, 1^{\prime}-\mathrm{H}\right), 3.80(\mathrm{~d}, J=16.4 \mathrm{~Hz}$, $\left.2 \mathrm{H}, 1^{\prime}-\mathrm{H}\right), 2.56\left(\mathrm{~s}, 3 \mathrm{H}, \mathrm{NCH}_{3}\right), 1.73-1.80\left(\mathrm{~m}, 2 \mathrm{H}, \mathrm{OCH}_{2}\right)$, 1.39-1.47 (m, 2H, $\left.\mathrm{OCH}_{2} \mathrm{CH}_{2}\right), 1.21-1.38\left(\mathrm{~m}, 24 \mathrm{H}, \mathrm{CH}_{2}\right), 0.87$ $\left(\mathrm{t}, J=7.0 \mathrm{~Hz}, 3 \mathrm{H}, \mathrm{CH}_{3}\right) \mathrm{ppm} .{ }^{13} \mathrm{C} \mathrm{NMR}\left(176 \mathrm{MHz}, \mathrm{CDCl}_{3}\right)$ $\delta=167.1(\mathrm{C}=0), 166.5(\mathrm{C}-5), 132.3(\mathrm{C}-2), 132.0(\mathrm{C}-4), 129.3$ (C-3), $65.3\left(\mathrm{OCH}_{2}\right), 61.9\left(\mathrm{C}-1^{\prime}\right), 47.6\left(\mathrm{NCH}_{3}\right), 29.31,31.93$, 29.70, 29.69, 29.66, 29.62, 29.56, 29.37, 28.72, 26.04, 22.70, $\left(\mathrm{CH}_{2}\right), 14.14\left(\mathrm{CH}_{3}\right)$ ppm. FT-IR (ATR): 2917 (vs), 2850 (s), 2165 (w), 1762 (s), $1719(\mathrm{w}), 1467$ (w), $1277(\mathrm{w}), 1114(\mathrm{w})$, $1041(w), 995(w), 842(w), 767(w), 711(w) \mathrm{cm}^{-1}$. MS (ESI): $m / z=501[\mathrm{M}]^{+}$. HRMS (ESI) $(m / z):[\mathrm{M}+\mathrm{Na}]^{+}$calcd. for $\mathrm{C}_{28} \mathrm{H}_{44} \mathrm{BNO}_{6} \mathrm{Na}$ 524.3159, found: 524.3165. CHN analysis calcd. (\%) for $\mathrm{C}_{28} \mathrm{H}_{44} \mathrm{BNO}_{6}$ (501.47): C 67.06, $\mathrm{H}$ 8.84, N 2.79; found: C 66.81, H $8.70 \mathrm{~N} 2.70$.

\section{3,3,4,4,5,5,6,6,7,7,8,8,8-Tridecafluorooctyl 4-(6- methyl-4,8-dioxo-1,3,6,2-dioxazaborocan-2-yl) benzoate (Est2.6 ${ }^{\mathrm{F}}$ )}

The general esterification procedure was followed with 5 and 1,1,2,2-H-perfluorooctanol to give Est2.6 $\mathbf{F}$ as a white solid (139 mg, 62\%).

${ }^{1} \mathrm{H}$ NMR $\left(500 \mathrm{MHz}, \mathrm{CDCl}_{3}\right): \delta=8.08(\mathrm{~d}, J=7.9 \mathrm{~Hz}, 2 \mathrm{H}$, 2-H), 7.66 (d, $J=7.9 \mathrm{~Hz}, 2 \mathrm{H}, 3-\mathrm{H}), 4.68(\mathrm{t}, J=6.4 \mathrm{~Hz}, 2 \mathrm{H}$, $\mathrm{OCH}_{2}$ ), 3.99 (d, $\left.J=16.4 \mathrm{~Hz}, 2 \mathrm{H}, 1^{\prime}-\mathrm{H}\right), 3.83(\mathrm{~d}, J=16.4 \mathrm{~Hz}$, $\left.2 \mathrm{H}, 1^{\prime}-\mathrm{H}\right), 2.54-2.73\left(\mathrm{~m}, 2 \mathrm{H}, \mathrm{OCH}_{2} \mathrm{CH}_{2}\right), 2.60\left(\mathrm{~s}, 3 \mathrm{H}, \mathrm{NCH}_{3}\right)$ ppm. ${ }^{13} \mathrm{C}$ NMR (101 MHz, $\left.\left(\mathrm{CD}_{3}\right)_{2} \mathrm{CO}\right): \delta=169.1(\mathrm{C}=\mathrm{O})$, 166.6 (C-5), 133.7 (C-2), 131.2 (C-4), 129.5 (C-3), 63.0 (C-1'), $57.6\left(\mathrm{OCH}_{2}\right), 48.4\left(\mathrm{NCH}_{3}\right), 30.1\left(\mathrm{p}, J=39.0 \mathrm{~Hz}, \mathrm{OCH}_{2} \mathrm{CH}_{2}\right)$ ppm. ${ }^{19} \mathrm{~F}$ NMR (376 MHz, $\left.\mathrm{CDCl}_{3}\right): \delta=-125.90$ to -126.19 (m), -123.33 to $-123.63(\mathrm{~m}),-122.61$ to $-122.98(\mathrm{~m})$, -121.64 to $-121.93(\mathrm{~m}),-113.29$ to $-113.57(\mathrm{~m}),-80.76$ (tt, $J=9.9 \mathrm{~Hz}, 2.6 \mathrm{~Hz}$ ) ppm. FT-IR (ATR): 1770 (s), 1730 (s), 1455 (w), 1397 (w), 1337 (w), 1275 (s), 1232 (s), 1187 (vs), $1143(\mathrm{~s}), 1121(\mathrm{~s}), 1036(\mathrm{~s}), 999(\mathrm{~s}), 964(\mathrm{w}), 889(\mathrm{w}), 841(\mathrm{~s})$, $810(w), 782(w), 765(s), 733(w), 708(s), 651(w), 598(w)$, $567(w), 531(w), 501(w), 454(w), 440(w) \mathrm{cm}^{-1}$. MS (ESI): $m / z=622\left[\mathrm{M}-\mathrm{H}^{+}\right]^{-}$. HRMS (ESI) $(m / z):\left[\mathrm{M}-\mathrm{H}^{+}\right]^{-}$calcd. for $\mathrm{C}_{20} \mathrm{H}_{14} \mathrm{BF}_{13} \mathrm{NO}_{6} 622.0705$, found: 622.0697. CHN analysis calcd. (\%) for $\mathrm{C}_{20} \mathrm{H}_{15} \mathrm{BF}_{13} \mathrm{NO}_{6}$ (623.13): $\mathrm{C} 38.55, \mathrm{H} \mathrm{2.43,} \mathrm{N}$ 2.25; found: C 38.51, H 2.63 N 2.13 .

\section{$3,3,4,4,5,5,6,6,7,7,8,8,9,9,10,10,10-$ Heptadecafluorooctyl 4-(6-methyl-4,8-dioxo- 1,3,6,2-dioxazaborocan-2-yl)benzoate (Est2.8 ${ }^{\mathrm{F}}$ )}

The general esterification procedure was followed with 5 and 1,1,2,2-H-perfluorodecanol to give Est2.8 ${ }^{\mathbf{F}}$ as a white solid (169 mg, 65\%).

${ }^{1} \mathrm{HNMR}\left(500 \mathrm{MHz},\left(\mathrm{CD}_{3}\right)_{2} \mathrm{CO}\right): \delta=8.02(\mathrm{~d}, J=8.1 \mathrm{~Hz}, 2 \mathrm{H}$, $2-\mathrm{H}), 7.70(\mathrm{~d}, J=8.1 \mathrm{~Hz}, 2 \mathrm{H} 3-\mathrm{H}), 4.69(\mathrm{t}, J=6.1 \mathrm{~Hz}, 2 \mathrm{H}$, $\left.\mathrm{OCH}_{2}\right), 4.40\left(\mathrm{~d}, J=17.0 \mathrm{~Hz}, 2 \mathrm{H}, 1^{\prime}-\mathrm{H}\right), 4.20(\mathrm{~d}, J=17.0 \mathrm{~Hz}$, $\left.2 \mathrm{H}, 1^{\prime}-\mathrm{H}\right), 2.82\left(\mathrm{~s}, 3 \mathrm{H}, \mathrm{NCH}_{3}\right), 2.75-2.94\left(\mathrm{~m}, 2 \mathrm{H}, \mathrm{OCH}_{2} \mathrm{CH}_{2}\right)$ ppm. ${ }^{13} \mathrm{CNMR}\left(126 \mathrm{MHz},\left(\mathrm{CD}_{3}\right)_{2} \mathrm{CO}\right): \delta=169.2(\mathrm{C}=\mathrm{O}), 166.6$ (C-5), 133.7 (C-2), 131.2 (C-4), 129.5 (C-3), 62.9 (C-1'), 57.6 $\left(\mathrm{OCH}_{2}\right), 48.4\left(\mathrm{NCH}_{3}\right), 30.1\left(\mathrm{p}, \mathrm{J}=38.7 \mathrm{~Hz}, \mathrm{OCH}_{2} \mathrm{CH}_{2}\right)$ ppm. ${ }^{19} \mathrm{~F}$ NMR (376 MHz, $\left.\left(\mathrm{CD}_{3}\right)_{2} \mathrm{CO}\right): \delta=-126.54$ to $-126.81(\mathrm{~m})$, -123.83 to $-124.16(\mathrm{~m}),-123.01$ to $-123.36(\mathrm{~m}),-121.94$ to $-122.55(\mathrm{~m}),-113.63$ to $-113.99(\mathrm{~m}),-81.64(\mathrm{t}, J=10.1 \mathrm{~Hz})$ ppm. FT-IR(ATR): 1766 (s), 1731 (s), $1455(\mathrm{w}), 1397$ (w), 1372 (w), 1334(w), 1274(s), $1201(\mathrm{vs}), 1146(\mathrm{~s}), 1115(\mathrm{~s}), 1071(\mathrm{w})$, 1036(s), $1003(\mathrm{~s}), 961(\mathrm{w}), 878(\mathrm{w}), 860(\mathrm{w}), 842(\mathrm{w}), 766(\mathrm{w})$, $738(w), 710(w), 654(w), 621(w), 595(w), 559(w), 530(w)$, 499 (w), 441 (w), 419 (w) $\mathrm{cm}^{-1}$. MS (ESI): $\mathrm{m} / z=746$ $[\mathrm{M}+\mathrm{Na}]^{+}$. HRMS (ESI) $(m / z):[\mathrm{M}+\mathrm{Na}]^{+}$calcd. for $\mathrm{C}_{22} \mathrm{H}_{15} \mathrm{BF}_{17} \mathrm{NO}_{6} \mathrm{Na} 746.0617$, found: 746.0614. CHN analysis calcd.(\%) for $\mathrm{C}_{22} \mathrm{H}_{15} \mathrm{BF}_{17} \mathrm{NO}_{6}$ (723.15): C 36.54, H 2.09, N 1.94; found: C 36.56, H $2.03 \mathrm{~N} 1.80$. 
$5,5,6,6,7,7,8,8,9,9,10,10,11,11,12,12,12-$ Heptadecafluorododecyl 4-(6-methyl-4,8-dioxo1,3,6,2-dioxazaborocan-2-yl)benzoate (Est4.8F)

The general esterification procedure was followed with $\mathbf{5}$ and $\mathbf{1 0}$ to give Est4.8 ${ }^{\mathbf{F}}$ as a white solid (116 mg, 43\%).

${ }^{1} \mathrm{HNMR}\left(500 \mathrm{MHz},\left(\mathrm{CD}_{3}\right)_{2} \mathrm{CO}\right): \delta=8.01(\mathrm{~d}, J=8.3 \mathrm{~Hz}, 2 \mathrm{H}$, 2-H), $7.69(\mathrm{~d}, J=8.3 \mathrm{~Hz}, 2 \mathrm{H}), 4.37-4.43\left(\mathrm{~m}, 4 \mathrm{H}, 1^{\prime}-\mathrm{H}, \mathrm{OCH}_{2}\right)$, 4.19 (d, $\left.J=17.1 \mathrm{~Hz}, 2 \mathrm{H}, 1^{\prime}-\mathrm{H}\right), 2.77\left(\mathrm{~s}, 3 \mathrm{H}, \mathrm{NCH}_{3}\right), 2.37$ (tt, $J=19.6 \mathrm{~Hz}, 8.0 \mathrm{~Hz}, 2 \mathrm{H}, 4 "-\mathrm{H}), 1.92-2.00$ (m, 2H, 2"-H), $1.79-1.89$ ( $\left.\mathrm{m}, 2 \mathrm{H}, 3^{\prime \prime}-\mathrm{H}\right) \mathrm{ppm} .{ }^{13} \mathrm{C} \mathrm{NMR}\left(126 \mathrm{MHz},\left(\mathrm{CD}_{3}\right)_{2} \mathrm{CO}\right)$ : $\delta=17.9$ (C-3"), 28.8 (C-2"), 30.1 (p, J=39.0 Hz, C-4") 48.4 $\left(\mathrm{NCH}_{3}\right), 62.9\left(\mathrm{C}-1^{\prime}\right), 64.9\left(\mathrm{OCH}_{2}\right), 129.4(\mathrm{C}-3), 131.8(\mathrm{C}-4), 133.7$ (C-2), $166.9(\mathrm{C}-5), 169.2(\mathrm{C}=0)$ ppm. ${ }^{19} \mathrm{~F}$ NMR (376 MHz, $\left.\mathrm{CDCl}_{3}\right): \delta=-125.95$ to $-126.13(\mathrm{~m}),-123.30$ to $-123.53(\mathrm{~m})$, -122.51 to $-122.77(\mathrm{~m}),-121.50$ to $-122.00(\mathrm{~m}),-114.25$ to $-114.49(\mathrm{~m}),-80.72(\mathrm{t}, J=9.5 \mathrm{~Hz}), \mathrm{ppm}$. FT-IR (ATR): 1765 (s), $1719(\mathrm{~s}), 1463(\mathrm{w}), 1396(\mathrm{w}), 1370(\mathrm{w}), 1333(\mathrm{w}), 1273(\mathrm{~s})$, 1199 (vs), 1146 (vs), 1114 (s), 1035 (s), 1002 (s), 961 (s), 928 (w), $888(w), 842(w), 807(w), 792(w), 767(s), 736(w), 705$ (s), $654(\mathrm{~s}), 621(\mathrm{w}), 595(\mathrm{w}), 559(\mathrm{w}), 529(\mathrm{w}), 460(\mathrm{w}) \mathrm{cm}^{-1}$. MS (ESI): $m / z=774[\mathrm{M}+\mathrm{Na}]^{+}$. HRMS (ESI) $(m / z):[\mathrm{M}+\mathrm{Na}]^{+}$ calcd. for $\mathrm{C}_{24} \mathrm{H}_{19} \mathrm{BF}_{17} \mathrm{NO}_{6} \mathrm{Na} 774.0930$, found: 774.0914. $\mathrm{CHN}$ analysis calcd.(\%) for $\mathrm{C}_{24} \mathrm{H}_{19} \mathrm{BF}_{17} \mathrm{NO}_{6}$ (751.20): C 38.37, $\mathrm{H} 2.55$, N 1.86; found: C 38.45, H 2.64 N 1.75 .

\section{Etherification: General Procedure}

Sodium hydride $(0.50 \mathrm{~g}, 12.5 \mathrm{mmol})$ was placed in the reaction flask and washed with pentane $(3 \times 5 \mathrm{~mL})$. DMF (20 mL) was added and the suspension was cooled to $0{ }^{\circ} \mathrm{C}$. The respective alcohol $(11.0 \mathrm{mmol})$ was added dropwise and the reaction mixture was stirred for $30 \mathrm{~min}$ at $0{ }^{\circ} \mathrm{C}$. 4-Bromobenzylbromide $\mathbf{9}$ ( $2.50 \mathrm{~g}, 10.0 \mathrm{mmol}$ ) was added in portions and the mixture was stirred at room temperature for $16 \mathrm{~h}$. The solvent was evaporated, water $(50 \mathrm{~mL})$ was added, and the product was extracted with $\mathrm{CH}_{2} \mathrm{Cl}_{2}$ $(3 \times 50 \mathrm{~mL})$. The combined organic layers were dried over $\mathrm{MgSO}_{4}$. Evaporation of the solvent gave the title compound which was used without further purification.

\section{1-Bromo-4-((nonyloxy)methyl)benzene (7a)}

The general etherification procedure was followed with 6 and 1-nonanol to give $7 \mathbf{a}$ as a white solid (2.29 g, 73\%).

${ }^{1} \mathrm{H}$ NMR (400 MHz, $\left.\mathrm{CDCl}_{3}\right): \delta=7.42-7.50(\mathrm{~m}, 2 \mathrm{H}, 2-\mathrm{H})$, 7.17-7.25 (m, 2H, 3-H), $4.44(\mathrm{~s}, 2 \mathrm{H}, 5-\mathrm{H}), 3.45$ (t, $J=6.6 \mathrm{~Hz}$, $\left.2 \mathrm{H},-\mathrm{OCH}_{2}\right), 1.53-1.67\left(\mathrm{~m}, 2 \mathrm{H},-\mathrm{OCH}_{2} \mathrm{CH}_{2}\right), 1.18-1.42(\mathrm{~m}, 12 \mathrm{H}$, $\left.\mathrm{CH}_{2}\right), 0.80-0.94\left(\mathrm{~m}, 3 \mathrm{H}, \mathrm{CH}_{3}\right)$ ppm. ${ }^{13} \mathrm{C} \mathrm{NMR}(101 \mathrm{MHz}$, $\left.\mathrm{CDCl}_{3}\right): \delta=137.8(\mathrm{C}-4), 131.4(\mathrm{C}-2), 129.2(\mathrm{C}-3), 121.3(\mathrm{C}-1)$, 72.1 (C-5), $70.7\left(-\mathrm{OCH}_{2}\right), 31.89,29.75,29.56,29.48,29.28$,
26.19, 22.68, $\left(\mathrm{CH}_{2}\right), 14.11\left(\mathrm{CH}_{3}\right), \mathrm{ppm}$. MS (EI): $m / z=312$ $[\mathrm{M}]^{+}$. HRMS (ESI) $(\mathrm{m} / \mathrm{z}):[\mathrm{M}+\mathrm{Na}]^{+}$calcd. for $\mathrm{C}_{16} \mathrm{H}_{25} \mathrm{BrONa}$ : 335.0981, found: 335.0974 .

\section{1-Bromo-4-((undecyloxy)methyl)benzene (7b)}

The general etherification procedure was followed with 6 and 1-undecanol to give $7 \mathbf{b}$ as a white solid (2.49 g, 65\%).

${ }^{1} \mathrm{H}$ NMR (400 MHz, $\left.\mathrm{CDCl}_{3}\right): \delta=7.43-7.49(\mathrm{~m}, 2 \mathrm{H}, 2-\mathrm{H})$, 7.17-7.25 (m, 2H, 3-H), $4.44(\mathrm{~s}, 2 \mathrm{H}, 5-\mathrm{H}), 3.45(\mathrm{t}, J=6.6 \mathrm{~Hz}$, $\left.2 \mathrm{H},-\mathrm{OCH}_{2}\right), 1.51-1.66\left(\mathrm{~m}, 2 \mathrm{H},-\mathrm{OCH}_{2} \mathrm{CH}_{2}\right), 1.19-1.41(\mathrm{~m}, 16 \mathrm{H}$, $\left.\mathrm{CH}_{2}\right), 0.83-0.92\left(\mathrm{~m}, 3 \mathrm{H}, \mathrm{CH}_{3}\right), \mathrm{ppm} .{ }^{13} \mathrm{C} \mathrm{NMR}(101 \mathrm{MHz}$, $\left.\mathrm{CDCl}_{3}\right): \delta=137.8(\mathrm{C}-4), 131.4(\mathrm{C}-2), 129.2(\mathrm{C}-3), 121.3(\mathrm{C}-1)$, 72.1 (C-5), $70.7\left(-\mathrm{OCH}_{2}\right), 31.92,29.75,29.62,29.60,29.48$, 29.35, 26.19, $22.70\left(\mathrm{CH}_{2}\right), 14.12\left(\mathrm{CH}_{3}\right), \mathrm{ppm}$. MS (EI): $\mathrm{m} / \mathrm{z}=$ $340[\mathrm{M}]^{+}$. HRMS (ESI) $(\mathrm{m} / \mathrm{z}):[\mathrm{M}+\mathrm{Na}]^{+}$calcd. for $\mathrm{C}_{18} \mathrm{H}_{29} \mathrm{BrONa}$ : 363.1294, found: 363.1290.

\section{Benzyl Ether Boronate Preparation: General Procedure}

The respective alkoxy-bromo-benzene $6(2.93 \mathrm{mmol})$ was dissolved in dry THF $(20 \mathrm{~mL})$ and cooled to $-78{ }^{\circ} \mathrm{C}$. $n$-BuLi $(1.9 \mathrm{~mL}, 4.69 \mathrm{mmol}, 2.5 \mathrm{M})$ was added and the mixture was stirred for $30 \mathrm{~min}$. Triisopropyl borate $(1.1 \mathrm{~mL}$, $4.69 \mathrm{mmol}$ ) was added and the reaction was allowed to warm up to room temperature over $2 \mathrm{~h}$. A solution of MIDA $(1.3 \mathrm{~g}, 8.79 \mathrm{mmol})$ in abs. DMSO $(18 \mathrm{~mL}, 0.5 \mathrm{M})$ was added and the mixture was refluxed for $2 \mathrm{~h}$. The reaction mixture was poured into water and extracted with $\mathrm{CH}_{2} \mathrm{Cl}_{2}$ $(3 \times 50 \mathrm{~mL})$. Combined organic layers were washed with brine $(50 \mathrm{~mL})$, dried with $\mathrm{MgSO}_{4}$, and the solvent was evaporated. The crude product was purified by flash chromatography (hexanes/ethyl acetate $1: 1 ; R_{\mathrm{f}}: 0.3$ ).

\section{6-Methyl-2-\{4-[(nonyloxy)methyl]phenyl]-1,3,6,2- dioxazaborocane-4,8-dione (BEth9)}

The general etherification procedure was followed for benzyl ether boronate preparation with 7a to give BEth9 as a white solid (741 mg, 65\%).

${ }^{1} \mathrm{H}$ NMR $\left(400 \mathrm{MHz}, \mathrm{CDCl}_{3}\right): \delta=7.47(\mathrm{~d}, J=7.7 \mathrm{~Hz}, 2 \mathrm{H}$, 2-H) $7.34(\mathrm{~d}, J=7.7 \mathrm{~Hz}, 2 \mathrm{H}, 3-\mathrm{H}), 4.48(\mathrm{~s}, 2 \mathrm{H}, 5-\mathrm{H}), 4.11(\mathrm{~d}$, $\left.J=16.8 \mathrm{~Hz}, 2 \mathrm{H}, 1^{\prime}-\mathrm{H}\right), 3.78\left(\mathrm{~d}, J=16.7 \mathrm{~Hz}, 2 \mathrm{H}, 1^{\prime}-\mathrm{H}\right), 3.48$ $\left(\mathrm{t}, J=6.7 \mathrm{~Hz}, 2 \mathrm{H}, \mathrm{CH}_{2} \mathrm{O}\right), 2.51\left(\mathrm{~s}, 3 \mathrm{H}, \mathrm{NCH}_{3}\right), 1.57-1.67(\mathrm{~m}$, $\left.2 \mathrm{H}, \mathrm{CH}_{2} \mathrm{CH}_{2} \mathrm{O}\right), 1.21-1.40\left(\mathrm{~m}, 12 \mathrm{H}, \mathrm{CH}_{2}\right), 0.83-0.92(\mathrm{~m}, 3 \mathrm{H}$, $\left.\mathrm{CH}_{3}\right)$, ppm. ${ }^{13} \mathrm{C}$ NMR $\left(101 \mathrm{MHz}, \mathrm{CDCl}_{3}\right): \delta=167.4(\mathrm{C}=0)$, 140.7 (C-4), 132.3 (C-2), 127.5 (C-3), 72.7 (C-5), 70.9 $\left(-\mathrm{OCH}_{2}\right), 61.8\left(\mathrm{C}-1^{\prime}\right), 47.49\left(\mathrm{NCH}_{3}\right), 29.77,29.57,29.52$, 29.28, 26.20, $22.67\left(\mathrm{CH}_{2}\right), 14.11\left(\mathrm{CH}_{3}\right)$ ppm. FT-IR (ATR): $2924(w), 2853(w), 1746$ (vs), $1613(w), 1457$ (w), $1697(w)$, 1338 (w), 1292 (s), 1229 (s), 1115 (w), 1099 (w), 1037 (s), 
$990.92(\mathrm{~s}), 890(\mathrm{w}), 865(\mathrm{w}), 807(\mathrm{w}), 710(\mathrm{w}), 653(\mathrm{w}), 593$ (w), $548(\mathrm{w}), 491(\mathrm{w}), 458(\mathrm{w}) \mathrm{cm}^{-1}$. MS (ESI): $\mathrm{m} / z=412$ $[\mathrm{M}+\mathrm{Na}]^{+}$. HRMS (ESI) $(\mathrm{m} / \mathrm{z}):[\mathrm{M}+\mathrm{Na}]^{+}$calcd. for $\mathrm{C}_{21} \mathrm{H}_{32} \mathrm{BNO}_{5} \mathrm{Na}: 412.2269$, found: 412.2290. CHN analysis calcd. (\%) for $\mathrm{C}_{21} \mathrm{H}_{32} \mathrm{BNO}_{5}$ (389.30): C $64.79 \mathrm{H} \mathrm{8.29,} \mathrm{N} \mathrm{3.60;}$ found: C 64.66, H 7.99 N 3.49 .

\section{6-Methyl-2-[4-[(undecyloxy)methyl]phenyl\}- 1,3,6,2-dioxazaborocane-4,8-dione (BEth11)}

The general etherification procedure was followed for benzyl ether boronate preparation with $\mathbf{7 b}$ to give BEth11 as a white solid (770 $\mathrm{mg}, 63 \%$ ).

${ }^{1} \mathrm{H}$ NMR (400 MHz, $\left.\mathrm{CDCl}_{3}\right): \delta=7.48(\mathrm{~d}, J=7.7 \mathrm{~Hz}, 2 \mathrm{H}$, 2-H), 7.36 (d, J = 7.7 Hz, 2H, 3-H), 4.49 (s, 2H, 5-H), 3.94-4.10 $\left(\mathrm{m}, 2 \mathrm{H}, 1^{\prime}-\mathrm{H}\right), 3.77\left(\mathrm{~d}, J=16.1 \mathrm{~Hz}, 2 \mathrm{H}, 1^{\prime}-\mathrm{H}\right), 3.48(\mathrm{t}, J=6.7 \mathrm{~Hz}$, $\left.2 \mathrm{H},-\mathrm{OCH}_{2}\right), 2.53\left(\mathrm{~s}, 3 \mathrm{H},-\mathrm{NCH}_{3}\right), 1.54-1.67\left(\mathrm{~m}, 2 \mathrm{H},-\mathrm{OCH}_{2} \mathrm{CH}_{2}\right)$, 1.19-1.42 (m, 16H, CH $), 0.84-0.91\left(\mathrm{~m}, 3 \mathrm{H}, \mathrm{CH}_{3}\right), \mathrm{ppm} .{ }^{13} \mathrm{C}$ NMR (101 MHz, $\left.\mathrm{CDCl}_{3}\right): \delta=167.2(\mathrm{C}=\mathrm{O}), 140.7(\mathrm{C}-4), 132.3$ (C-2), 127.5 (C-3), 72.7 (C-5), $70.9\left(-\mathrm{OCH}_{2}\right), 61.8\left(\mathrm{C}-1^{\prime}\right), 47.4$ $\left(\mathrm{NCH}_{3}\right), 31.92,29.77,29.63,29.52,29.34,26.21,22.69,\left(\mathrm{CH}_{2}\right)$, $14.12\left(\mathrm{CH}_{3}\right)$ ppm. FT-IR (ATR): 2922 (s), 2853 (w), 1761 (vs), 1612 (w), 1457 (w), 1397 (w), 1338 (w), 1293 (s), 1230 (s), $1115(w), 1100(w), 1038$ (s), $991(w), 890(w), 865(w), 807$ (w), $710(w), 653(w), 593(w), 548(w), 491(w), 458(w) \mathrm{cm}^{-1}$. MS (ESI): $m / z=440[\mathrm{M}+\mathrm{Na}]^{+}$. HRMS (ESI) $(m / z):[\mathrm{M}+\mathrm{Na}]^{+}$ calcd. for $\mathrm{C}_{23} \mathrm{H}_{36} \mathrm{BNO}_{5} \mathrm{Na}$ : 440.2579, found: 440.2596. $\mathrm{CHN}$ analysis calcd. (\%) for $\mathrm{C}_{23} \mathrm{H}_{36} \mathrm{BNO}_{5}$ (417.35): $\mathrm{C} 66.19 \mathrm{H} \mathrm{8.69,} \mathrm{N}$ 3.36; found: C 65.94, H 8.55 N 3.27.

\section{Quantum Chemical Calculations}

We employed Møller-Plesset second-order perturbation theory (MP2) and a def2-TZVPP basis set and appropriate auxiliary basis sets for efficient two-electron integral evaluation. ${ }^{52-54}$ Full-structure optimizations were carried out at this level of theory and dipole moments and electrostatic potentials were evaluated from the relaxed one-electron density. The TURBOMOLE program package $^{55,56}$ was used throughout; graphical representations were generated by the TmoleX program (Version 4.5.2). ${ }^{57}$

\section{Funding Information}

Generous financial support by the Ministerium für Wissenschaft, Forschung und Kunst des Landes Baden-Württemberg, the Fonds der Chemischen Industrie, the Deutsche Forschungsgemeinschaft, and the Carl-Schneider-Stiftung Aalen (shared instrumentation grant) is gratefully acknowledged.

\section{Supporting Information}

Supporting information for this article is available online at http://doi.org/10.1055/s-0040-1715900.

\section{References}

(1) Mula, S.; Frein, S.; Russo, V.; Ulrich, G.; Ziessel, R.; Barberá, J.; Deschenaux, R. Chem. Mater. 2015, 27, 2332.

(2) Florian, A.; Mayoral, M. J.; Stepanenko, V.; Fernández, G. Chemistry 2012, 18, 14957.

(3) Olivier, J.-H.; Barberá, J.; Bahaidarah, E.; Harriman, A.; Ziessel, R. J. Am. Chem. Soc. 2012, 134, 6100.

(4) Benstead, M.; Rosser, G. A.; Beeby, A.; Mehl, G. H.; Boyle, R. W. New J. Chem. 2011, 35, 1410.

(5) Benstead, M.; Rosser, G. A.; Beeby, A.; Mehl, G. H.; Boyle, R. W. Photochem. Photobiol. Sci. 2011, 10, 992.

(6) Olivier, J.-H.; Camerel, F.; Ulrich, G.; Barberá, J.; Ziessel, R. Chemistry 2010, 16, 7134.

(7) Frein, S.; Camerel, F.; Ziessel, R.; Barberá, J.; Deschenaux, R. Chem. Mater. 2009, 21, 3950.

(8) Camerel, F.; Ulrich, G.; Barberá, J.; Ziessel, R. Chemistry 2007, 13, 2189.

(9) Cavero, E.; Lydon, D. P.; Uriel, S.; de la Fuente, M. R.; Serrano, J. L.; Giménez, R. Angew. Chem. Int. Ed. 2007, 46, 5175.

(10) Cavero, E.; de la Fuente, M. R.; Beltrán, E.; Romero, P.; Serrano, J. L.; Giménez, R. Chem. Mater. 2007, 19, 6230.

(11) Camerel, F.; Bonardi, L.; Schmutz, M.; Ziessel, R. J. Am. Chem. Soc. 2006, 128, 4548.

(12) Camerel, F.; Bonardi, L.; Ulrich, G.; Charbonnière, L.; Donnio, B.; Bourgogne, C.; Guillon, D.; Retailleau, P.; Ziessel, R. Chem. Mater. 2006, 18, 5009.

(13) Bando, Y.; Sakurai, T.; Seki, S.; Maeda, H. Chem. Asian J. 2013, 8, 2088.

(14) Terashima, Y.; Takayama, M.; Isozaki, K.; Maeda, H. Chem. Commun. 2013, 49, 2506.

(15) Mayoral, M. J.; Ovejero, P.; Campo, J. A.; Heras, J. V.; Oliveira, E.; Pedras, B.; Lodeiro, C.; Cano, M. J. Mater. Chem. 2011, 21, 1255.

(16) Turanova, O. A.; Turanov, A. N.; Lapaev, D. V.; Gnezdilov, O. I.; Lobkov, S. V.; Galyametdinov, Y.G. Russ.J. Gen. Chem. 2006, 76, 730.

(17) Turanova, O. A.; Kal'dyaeva, E. V.; Gnezdilov, O. I.; Nikitin, S. I.; Turanov, A. N. Russ. J. Gen. Chem. 2010, 80, 258.

(18) Sánchez, I.; Mayoral, M. J.; Ovejero, P.; Campo, J. A.; Heras, J. V.; Cano, M.; Lodeiro, C. New J. Chem. 2010, 34, 2937.

(19) Sánchez, I.; Núñez, C.; Campo, J. A.; Torres, M. R.; Cano, M.; Lodeiro, C. J. Mater. Chem. C 2014, 2, 9653.

(20) Tatum, L. A.; Johnson, C.J.; Fernando, A. A. P.; Ruch, B.C.; Barakoti, K. K.; Alpuche-Aviles, M. A.; King, B. T. Chem. Sci. 2012, 3, 3261.

(21) Wöhrle, T.; Baro, A.; Laschat, S. Materials 2014, 7, 4045.

(22) Belloni, M.; Manickam, M.; Wang, Z.-H.; Preece, J. A. Mol. Cryst. Liq. Cryst. 2003, 399, 93.

(23) Ringstrand, B.; Kaszynski, P. J. Mater. Chem. 2010, 20, 9613.

(24) Ringstrand, B.; Kaszynski, P. J. Mater. Chem. 2011, 21, 90.

(25) Pecyna, J.; Kaszyński, P.; Ringstrand, B.; Bremer, M. J. Mater. Chem. C 2014, 2, 2956.

(26) Pecyna, J.; Ringstrand, B.; Domagała, S.; Kaszyński, P.; Woźniak, K. Inorg. Chem. 2014, 53, 12617.

(27) Ringstrand, B.; Monobe, H.; Kaszynski, P. J. Mater. Chem. 2009, 19, 4805.

(28) Jankowiak, A.; Sivaramamoorthy, A.; Pociecha, D.; Kaszyński, P. RSC Adv. 2014, 4, 53907. 
(29) Tschierske, C. Top. Curr. Chem. 2012, 318, 1.

(30) Jang, J. Y.; Park, Y. W. Liq. Cryst. 2013, 40, 511.

(31) Ciastek, S.; Szymańska, K.; Kaszyński, P.; Jasiński, M.; Pociecha, D. Liq. Cryst. 2018, 45, 11.

(32) Liu, Z.; Zhang,J.; Li, T.; Yu, Z.; Zhang, S.J. Fluorine Chem. 2013, 147, 36.

(33) Kovářová, A.; Kozmík, V.; Svoboda, J.; Novotná, V.; Glogarová, M.; Pociecha, D. Liq. Cryst. 2012, 39, 755.

(34) Pibiri, I.; Beneduci, A.; Carraro, M.; Causin, V.; Casella, G.; Corrente, G. A.; Chidichimo, G.; Pace, A.; Riccobono, A.; Saielli, G. J. Mater. Chem. C 2019, 7, 7974.

(35) Wöhrle, T.; Gündemir, R.; Frey, W.; Knecht, F.; Köhn, A.; Laschat, S. Chemistry 2017, 23, 4149.

(36) Goodby, J. W.; Davis, E. J.; Mandle, R. J.; Cowling, S. J. Handbook of Liquid Crystals, Vol. 1, 2nd ed. Wiley-VCH: Weinheim; 2014, 231-260.

(37) Uno, B. E.; Gillis, E. P.; Burke, M. D. Tetrahedron 2009, 65, 3130.

(38) Gillis, E. P.; Burke, M. D. J. Am. Chem. Soc. 2007, 129, 6716.

(39) Fujii, S.; Chang, S. Y.; Burke, M. D. Angew. Chem. Int. Ed. 2011, 50, 7862.

(40) Gillis, E. P.; Burke, M. D. J. Am. Chem. Soc. 2008, 130, 14084.

(41) Jin, C.; Lee, H.; Lee, S.; Kim, I.; Jung, Y. Synlett 2007, 2007, 2695.

(42) Butschies, M.; Haenle, J. C.; Tussetschläger, S.; Laschat, S. Liq. Cryst. 2013, 40, 52.

(43) Inanaga, J.; Hirata, K.; Saeki, H.; Katsuki, T.; Yamaguchi, M. Bull. Chem. Soc. Jpn. 1979, 52, 1989.
(44) Lukin, K.; Kishore, V.; Gordon, T.Org. Process Res. Dev. 2013, 17, 666.

(45) Boger, D. L.; Johnson, D. S.; Yun, W. J. Am. Chem. Soc. 1994, 116, 1635.

(46) Hanwell, M. D.; Curtis, D. E.; Lonie, D. C.; Vandermeersch, T.; Zurek, E.; Hutchison, G. R. J. Cheminf. 2012, 4, 17.

(47) Haenle, J. C.; Stöckl, Y.; Forschner, R.; Haenle, E.; Laschat, S. ChemPhysChem 2018, 19, 2758.

(48) Ballmer, S. G.; Gillis, E. P.; Burke, M. D. Org. Synth. 2009, 86, 344.

(49) Wolfsberger, W.; Schmidbaur, H. Synth. React. Inorg. Met.-Org. Chem. 1974, 4, 149.

(50) Kornath, A.; Neumann, F.; Oberhammer, H. Inorg. Chem. 2003, 42, 2894.

(51) Ramachandran, P.V.; Nicponski, D.; Kim, B. Org. Lett. 2013, 15, 1398.

(52) Weigend, F.; Häser, M. Theor. Chem. Acc. 1997, 97, 331.

(53) Weigend, F.; Ahlrichs, R. Phys. Chem. Chem. Phys. 2005, 7, 3297.

(54) Weigend, F.; Häser, M.; Patzelt, H.; Ahlrichs, R. Chem. Phys. Lett. 1998, 294, 143.

(55) TURBOMOLE V7 1 2016, a development of University of Karlsruhe and Forschungszentrum Karlsruhe GmbH, 1989-2007, TURBOMOLE GmbH, since 2007; http://www.turbomole.com (accessed Aug 6, 2020).

(56) Furche, F.; Ahlrichs, R.; Hättig, C.; Klopper, W.; Sierka, M.; Weigend, F. WIREs Comput. Mol. Sci. 2014, 4, 91.

(57) Steffen, C.; Thomas, K.; Huniar, U.; Hellweg, A.; Rubner, O.; Schroer, A. J. Comput. Chem. 2010, 31, 2967. 